\title{
A kis apollólepke (Parnassius mnemosyne (LINNAEus, 1758)) nektárnövényfajok közti választása
}

\author{
VAJNA FLÓRA $^{{ }^{*}}$, SZIGETI VIKTOR ${ }^{2}$, HARNOS ANDREA ${ }^{3}$ éS KIS JÁNOS $^{1}$ \\ ${ }^{1}$ Állatorvostudományi Egyetem, Budapest, Ökológiai Tanszék, 1077 Budapest, Rottenbiller utca 50. \\ ${ }^{2}$ Ökológiai Kutatóközpont, Lendület Ökoszisztéma-szolgáltatás Kutatócsoport, 2163 Vácrátót, Alkotmány út 2. \\ ${ }^{3}$ Állatorvostudományi Egyetem, Budapest, Biomatematikai és Számítástechnikai Tanszék, \\ 1078 Budapest, István utca 2. *E-mail: vajnaflora@yahoo.com
}

\begin{abstract}
Kivonat. A lepkék jó modelljei lehetnek a táplálékforrás-választás tanulmányozásának, mert a kifejlett egyedek válogatnak a nektárforrás-kínálatból és képesek alkalmazkodni időben változó táplálékforrásaikhoz. Célunk a kis apollólepke (Parnassius mnemosyne (LinNAEus, 1758)) nektárnövényfajválasztását befolyásoló virágtulajdonságok megismerése volt. A vizsgált populációk egyedeit jelölésvisszalátás módszerrel mintavételeztük 5, majd 2 éven keresztül két egymáshoz közeli réten a Visegrádi-hegységben. A virággyakoriságot bejárásos módszerrel becsültük. A virágtulajdonságokat a Biolflor adatbázisból gyüjtöttük. Az évenkénti viráglátogatási arány változott a növényfajok között. Nagy változatosságot találtunk az elérhető növények tulajdonságaiban és a virágkínálatban az egyes évek és a két rét között. A lepkék választását a virágok gyakorisága, színe és típusa, valamint a rovarbeporzás szerepe befolyásolta az egyik, míg csupán a virággyakoriság és a virágszín a másik réten. A növények beporzóik választását befolyásoló tulajdonságai egymástól valószínűleg nem függetlenek. A viráglátogatási mintázat mindkét élőhelyen arra utal, hogy a kis apollólepkék választanak elérhető forrásaik közül. A két rét populációi közötti különbség azt sugallja, hogy a választás környezetfüggő. Valószínű, hogy az energiabefektetés-arányosan kinyerhető legtöbb és/vagy legjobb nektárt nyújtó fajokat látogatják a leggyakrabban. Ahhoz, hogy egy élőhely megfelelő legyen egy adott lepkefaj számára, elsődleges szempont a lárvális tápnövény jelenléte, ám az imágók táplálékát biztosító nektárnövények kellő mennyiségü előfordulása is nélkülözhetetlen lehet.
\end{abstract}

Kulcsszavak: forráshasználat, nektárforrás, növény-beporzó kapcsolat, táplálékkeresés, táplálékkínálat.

\section{Bevezetés}

A táplálkozás meghatározza az állatok túlélését és szaporodási sikerét (STEPHENS et al. 2007). A táplálékforrások elérhetősége, tér- és időbeli változatossága alakítja a fogyasztók viselkedését, túlélését, populációméretét, és ennek következtében a közösségek összetételét (STEFFAN-DEWENTER \& TSCHARNTKE 1999; STEPHENS et al. 2007; CURTIS et al. 2015). Az állatok táplálékszükségleteiknek megfelelően és lehetőségeikhez mérten választanak a rendelkezésükre álló táplálékforrásokból. Noha számos hipotézis jól magyarázza a források és a táplálkozás közötti összefüggéseket (PYKE et al. 1977; WILSON 1998; GOULSON 1999; STEPHENS et al. 2007), az állatok táplálkozási viselkedésének sok részlete még isme- 
retlen, pl. az, hogy mi alapján választják ki táplálékukat a rendelkezésre álló források közül. A növény-beporzó kapcsolatoknál fontos annak ismerete, hogy a beporzó milyen növényi tulajdonságok alapján választja ki azt a virágot, amelyikből táplálkozik. A növények virágaikkal állatokat, pl. méheket, gekkókat, kolibrikat és denevéreket csalogatnak magukhoz, és azok végzik el a beporzást (WILLMER 2011). A „csalogatás” egyik fontos része, hogy a beporzók táplálékhoz, pl. virágporhoz (pollen) és nektárhoz juthatnak. A növény-beporzó kapcsolatok azért fontosak, mert több, mint negyedmillió növényfaj szaporodása állatokhoz kötött, esetükben a beporzást 130-300 ezer viráglátogató faj végzi (WILLMER 2011). A viráglátogató rovarok nagy részének táplálkozási viselkedéséről nehéz részletes, jó minőségü adatokat gyüjteni, de egyes lepkefajok táplálkozás közben könnyen megfigyelhetőek, így a forráshasználat vizsgálatának alkalmas alanyai lehetnek (LEBEAU et al. 2016).

A lepkék (Lepidoptera) hernyóinak többsége növényevö (herbivór); lehetnek mono-, oligo- és polifágok is (SCHOONHOVEN et al. 2005). A fajok zömének kifejlett egyedei, az imágók, virágos növények nektárját fogyasztják és azok fontos beporzói lehetnek (JOHNSON \& BOND 1994; CONNER et al. 1995; WARDHAUGH 2015), mint pl. egyes szegfüféléknek [Caryophyllaceae], (JENNERSTEN 1988; BLOCH et al. 2006), vagy akár gazdaságilag fontos növényfajoknak is (ABROL 2012). A többféle eltérö, hernyóként és kifejlett lepkeként felvett forrásból származó táplálék változatos fehérjékben, szénhidrátokban és ásványi anyagokban (ERHARDT \& MEVI-SCHÜTZ 2009). A különböző életszakaszokban felvett táplálék minősége és mennyisége egyaránt hatással lehet a lepkék szaporodási sikerére és élettartamára (BOGGS 1997; BRIEN et al. 2004; MEVI-SCHÜTZ \& ERHARDT 2005; CAHENZLI \& ERHARDT 2013; LEBEAU et al. 2016).

A kifejlett nappali lepkék alapvetően vizet és szénhidrátokat, valamint aminosavakat, szterolokat, vitaminokat és ásványi anyagokat igényelnek (ERHARDT \& MEVI-SCHÜTZ 2009). A virágok termelte nektár víz mellett változó mennyiségben cukrokat, föként szacharózt, glükózt és fruktózt, kisebb mennyiségben aminosavakat, zsírokat, olykor alkaloidokat és antioxidánsokat (pl. aszkorbinsavat) tartalmaz (BAKER \& BAKER 1983; NICOLSON et al. 2007; ABROL 2012). A lepkék szaporodási sikerét és túlélését a víz és a cukor mellett a nektárok aminosav-tartalma is növelheti (HILl 1989; MEVI-SCHÜTZ \& ERHARDT 2005; CAHENZLI \& ERHARDT 2013). A nektár ízét a cukrok és az aminosavak aránya határozza meg; a lepke-porozta növények többnyire szacharózban gazdagok (BAKER \& BAKER 1983; ERHARDT 1991; ERHARDT \& MEVI-SCHÜTZ 2009). A cukorkoncentráció növekedésével nő az energiatartalom, de a viszkozitás is, ami miatt nehezebbé válik a nektár felvétele (KIM et al. 2011). A lepkék számára a nektárok optimális cukorkoncentrációja 20-45\% (KIM et al. 2011; WILLMER 2011). A termelt nektár összetétele és mennyisége növényfajok között eltér, genetikailag részben meghatározott, de nagyon változatos lehet (GILBERT et al. 1991; NiCOLSON et al. 2007; WILLMER 2011; HICKS et al. 2016) és azt számtalan tényezö befolyásolja (BAKER \& BAKER 1983; NICOLSON et al. 2007; FARKAS et al. 2012). Bár a virágpor tartalmaz fehérjéket, szénhidrátokat, vizet, olajokat, ásványi sókat és vitaminokat (HALMÁGYI \& KERESZTESI 1991; NICOLSON 2007; WILLMER 2011), a lepkék számára nem jelentős táplálékforrás. Az ősi rágó szájszervből később kialakult, csővé záródott pödörnyelv, ami a ma élő lepkefajok többségének hosszú szájszerve (Glossata; KRENN 2010), valószínúleg alkalmatlan szemcsés anyagok felvételére (O’BRIEN et al. 2003; ERHARDT \& MEVI-SCHÜTZ 2009). Kevés pollent is fogyasztó lepkefajt ismerünk, ilyenek pl. a rágó szájszervvel rendelkező ősmolyok (Micropterigidae; KRENN 2010). 
Néhány lepkefaj imágója nektár mellett vagy helyett más forrásokból táplálkozik, ezekből olyan anyagokhoz jut, amelyek nektárokban nem vagy csak alig fordulnak elö, vagy olyan élőhelyen él, ahol kevés a nektárforrás (SETTELE et al. 2008). Egyes fajok egyéb növényi nedvekből cukrokhoz és fermentumokhoz jutnak (KNOPP \& KRENN 2003; OMURA et al. 2008), mások rothadó gyümölcsből etanolhoz és ecetsavhoz (OMURA et al. 2008), ürülékből, tetemekből aminosavakhoz és nitrogénhez (O’BRIEN et al. 2003), vérből fehérjékhez és nátriumhoz (PLOTKIN \& GODDARD 2013), szemfolyadékból fehérjékhez és sókhoz (HILGARTNER et al. 2007; PLOTKIN \& GODDARD 2013), pocsolyákból és sárból nitrogénhez (O’BRIEN et al. 2003) és a talajból kioldódott ásványi anyagokhoz (KRENN 2001; Hilgartner et al., 2007; ERHARDT \& MEVI-SchÜTZ 2009; STANG et al. 2009; KRENN 2010). Vannak olyan fajok is, melyek csak a lárvastádiumban felhalmozott tápanyagokból élnek, felnőttként nem táplálkoznak (MAY 1992; BOGGS \& FREEMAN 2005; ERHARDT \& MEVI-SCHÜTZ 2009; WILLMER 2011).

A kifejlett lepkék választanak a nektárforrás-kínálatból (BĄKOWSKI \& BOROŃ 2005; ERHARDT \& MEVI-SCHÜTZ 2009; THOMAS \& SCHULTZ 2016), képesek igazodni annak gyors időbeni változásához (KANDORI \& OHSAKI 1996; BLACKISTON et al. 2011; HANTSON \& BAZ 2013), ugyanakkor rövid időtartamon belül sorozatban ugyanazon növényfaj különböző virágain táplálkozva figyelhetjük meg őket (LEWIS 1989; CORY \& GOULSON 1993; ERHARDT \& MEVI-SCHÜTZ 2009). A választás a megfelelö táplálékbevitel miatt fontos, az ugyanazon nektárnövényfaj egymást követő látogatása pedig növelheti a táplálkozás hatékonyságát, a forrás felismerését, gyakorlással csökkentve a virág nektáriumának megtalálásához szükséges időt (GOULSON 1999). A nektártermelö, rovarporozta virágfajok érdekeltek az ismételt látogatásban, mert ez biztosítja a beporzást (ANDERSSON 2003; WILLMER 2011), így a magprodukciót is, ezáltal a beporzók hatnak a következő évek nektárnövénykínálatára, táplálékforrásaik populációinak méretére (KUNIN 1997; MAHORO 2002; ELZINGA et al. 2007; NICOLSON et al. 2007). A növényközösségek fajgazdagsága a lepkék számára nyújtott táplálékkínálaton keresztül befolyásolja a lepkeközösségek diverzitását (KiTAHARA et al. 2008; KUBO et al. 2009; WALLISDEVRIES et al. 2012).

A természetes, valamint a mezőgazdasági ökoszisztémák stabilitását veszélyezteti a beporzó rovarok számának világszerte tapasztalható csökkenése (POTTS et al. 2010; BURKLE et al. 2013). Ebben valószínüleg nagy szerepet játszik a jelenlegi tájhasználat, az élőhelypusztulás és -feldarabolódás okozta virággyakoriság- és növényfajgazdagság-csökkenés (PotTs et al. 2010; WALLISDEVRIES et al. 2012). Mivel a beporzó rovarok és a hozzájuk kötődő növények között szoros kapcsolat van, már kis változások is (pl. a beporzók és/vagy a virágok egyedszámváltozása, időbeli eltolódás a virágzás és a növény beporzóinak jelenléte között) nagy hatással lehetnek egész közösségekre. A beporzók egyedszámának csökkenésével pl. alacsonyabb lesz a megtermékenyített virágok aránya, kisebb lesz a maghozam, kevesebb magból pedig a következő évben kevesebb növény fejlödik (HEGLAND et al. 2009). Ha nem egy időben virágzik a növény a beporzó faj(ok) rajzásával, akkor elmarad a virágok megtermékenyítése, ami a növények alacsonyabb szaporodási sikeréhez vezet, valamint éheznek a beporzóik (HEGLAND et al. 2009). A növény-beporzó közösségeket ezért sebezhetőnek tartják (KEARNS \& INOUYE 1993; POTTS et al. 2010; NILSSON et al. 2013). Mivel többszázezer növényfaj fennmaradása múlik azon, hogy a növény-beporzó kapcsolatok, hálózatok megfelelően müködnek-e (WILLMER 2011), hatékony természetvédelmi stratégiák kidolgozásához elengedhetetlen, hogy részletes ismeretekkel rendelkez- 
zünk a védett fajok státuszáról: előfordulásukról, populációméretükröl, sebezhetőségükről és az ezeket meghatározó ökológiai tényezőkröl (NEW et al. 1995; SIMBERLOFF 1998; SUTHERLAND 2000; DiCKS et al. 2013). Ennek ellenére számos faj, köztük a legtöbb védett rovar ökológiai igényeiröl hiányosak az ismereteink (NEW 2012). A lepkék felnőttkori táplálkozásáról ugyancsak szükös ismeretekkel rendelkezünk (TUDOR et al. 2004; MATTER et al. 2009). Kevés tanulmány vizsgálja terepi megfigyelésekkel a nektárnövények közötti választást (JENNERSTEN 1984; THOMAS \& SCHULTZ 2016), valamint a viráglátogatás és a virágkínálat közötti időben változó kapcsolatokat (STEFANESCU 1997; BĄKOWSKI \& BOROŃ 2005; PRATT \& WIESENBORN 2009; SZIGETI et al. 2018). Megfelelö fajmegőrzési stratégiák kidolgozásához fontos lehet a lepkék felnőttkori forráshasználatának részletes ismerete is (DENNIS 2010; NEW 2012; Dicks et al. 2013; THOMAS \& SCHULTZ 2016). A lepkék táplálkozási viselkedésével foglalkozó vizsgálatok hozzájárulhatnak a növény-beporzó kapcsolatok megértéséhez, természetvédelmi stratégiák kidolgozásához, és modellrendszerekként segíthetnek akár olyan, a mezőgazdaságban is jelentős folyamatok megértésében, mint a beporzás (ALBRECHT et al. 2007; ABROL 2012).

Vizsgálatunkban a következő kérdésekre kerestük a választ: (1) milyen nektárnövényfajokat látogatnak a kis apollólepkék (Parnassius mnemosyne (LINNAEUS, 1758); Lepidoptera: Papilionidae) a rendelkezésükre álló virágos növények közül, és (2) milyen virágtulajdonságok határozzák meg a növényfajok közötti választást. E faj imágói sok időt töltenek táplálkozással (KONVIČKA \& KURAS 1999; VOJNITS \& ÁCS 2000; SZIGETI 2018). Táplálkozásuk könnyen megfigyelhető, megfelelö élőhelyen visszalátási valószínüségük magas lehet (KONVIČKA \& KURAS 1999; KUUSSAARI et al. 2016), az ivarok könnyen elkülöníthetöek (WEISS 1999), ezért megfelelö alanyai mind populációs, mind egyedi szintű nektárnövény-választást és táplálkozási viselkedést célzó vizsgálatoknak.

A kis apollólepke olyan területeken él, ahol a lárvakori tápnövénye kellő mennyiségben elöfordul és ehhez közel az imágóknak szükséges nektárnövényekben gazdag, napos, nyílt élőhelyek találhatóak (VAN HELSDINGEN et al. 1996; WeISS 1999; KUUSEMETS et al. 2005; KONVIČKA et al. 2006; VAN SWAAY et al. 2010). Magyarországon gyakori domb- és hegyvidéki faj, április végétöl július elejéig repül (RONKAY 1997). A hernyók kizárólag keltikefajokon (Corydalis spp.) táplálkoznak, hazánkban az odvas (C. cava) és az ujjas keltikét (C. solida) fogyasztják (MEGLÉCZ et al. 1997). Az imágók eltérő nektárforrásokat látogatnak különbözö élöhelyeiken (KUDRNA \& SEUFERT 1991; VAN HELSDINGEN et al. 1996; VOJNITS \& ÁCS 2000; KONVIČKA et al. 2001; KONVIČKA et al. 2006; LARA RUIZ 2011; PECSENYE 2017; SZIGETI 2018).

A kis apollólepkét a Berni Egyezmény védi, hazai (13/2001. (V. 9.) KöM rendelet 2. számú melléklet) és európai Vörös Listás faj (VAN SWAAY et al. 2010). Populációinak száma és mérete Európa-szerte csökken (WeISS 1999; KUUSSAARI et al. 2007; SETTELE et al. 2008, CINI et al. 2020). Ebben jelentős szerepe lehet a számukra kedvezö, geofitonokban gazdag lomberdők lecserélésének tülevelü állományokra (KONVIČKA \& KURAS 1999; FELTON et al. 2010). Európai elterjedési területének déli és északi határai a XX. század második felében északabbra tolódtak, feltehetően a klímaváltozás következtében (PARMESAN et al. 1999). E kedvezőtlen tendenciák folytatódása várható, ezáltal élőhelyeik száma tovább csökkenhet (WILSON \& MACLEAN 2011; SCHWEIGER et al. 2012), és néhány évtized múlva hazánkból el is tünhet (SETTELE et al. 2008). E faj hatékony védelme érdekében szükség van ökológiai igényeinek, így táplálkozási viselkedésének ismeretére. 


\section{Módszerek}

\section{Helyszín és időszak}

Vizsgálataink a Visegrádi-hegység két helyszínén, a Leány-kúti réten (4744'23,20"É; $19^{\circ} 03^{\prime} 33,42^{\prime \prime K}, 300$ m tengerszint feletti magasság, 0,6 hektár) 2009-2013 között (5 év) és a Hegyesden $\left(47^{\circ} 45^{\prime} 22,62^{\prime \prime E ́} ; 1^{\circ} 02^{\prime} 49,54^{\prime \prime K}, 295\right.$ m tengerszint feletti magasság, 0,5 hektár) 2014-2015 között (2 év) április végétől június elejéig folytak. A két élőhely egymástól kb. 2 km-re található, azokat egymástól zárt erdő választja el, közöttük a kis apollólepkék diszperzióját nem észleltük, jóllehet nyílt élőhelyeken jelölés-visszafogás vizsgálattal kb. 3 km-es elmozdulásukat is megfigyelték (KÖRÖSI Á. szóbeli közlés). E kis területű élőhelyeken kevés mintavételező személlyel is részletes jelölés-visszafogás vizsgálatot végezhettünk a teljes ott élő állományon.

A kis apollólepkéket a repülési időszak alatt az esős és/vagy nagyon hideg napokat kivéve (amikor a lepkék inaktívak; vizsgálatunk ideje alatt a repülési időszak átlagosan 12\%a volt ilyen) minden nap mintavételeztük kb. 9:00-17:00 (Leány-kúti rét), valamint 9:00 18:00 (Hegyesd) között. A különbséget az eltérő kitettség okozta, a Leány-kúti rét délután hamarabb került árnyékba, mint a Hegyesd, és a kis apollólepkék árnyékban inaktívvá válnak. A mintavételt néhány nappal a várt repülési időszak előtt kezdtük.

\section{Kis apollólepke mintavétel}

A lepkéket jelölés-visszalátás módszerrel mintavételeztük. Lassú tempóban naponta több alkalommal körbejártuk a teljes területet. A mintavétel során mindkét réten állandó, keskeny ösvényeket használtunk, hogy mérsékeljük a taposást. Az összes észlelt kis apollólepkét feljegyeztük. A jelöletlen példányokat befogtuk és egyedileg jelöltük. A jelölés részben egy egyedi azonosítószámból állt, amit a hátsó szárny fonákjára (ventrális oldalára) fekete alkoholos filctollal írtunk, részben egy három pöttyből álló színkódból, amit edding® lakkrost-tollal festettünk az elülső szárny hasi oldalának csúcsi részére, ahol átlátszó a szárny, így a kód mind a szárny felszínéről (dorzális oldaláról), mind fonákjáról távcsővel leolvasható volt. A szám a befogás során olvasható biztonsági jelölés az elülső szárnycsúcs sérülésének esetére. Nem észleltük, hogy az általunk használt jelölés a lepkék viselkedését befolyásolta volna. Amikor egy egyedet táplálkozni láttunk, feljegyeztük a színkódját, ivarát, az észlelés időpontját, valamint a látogatott növényfajt.

\section{Virággyakoriság mintavételezése}

A virággyakoriságot bejárásos módszerrel becsültük (SZIGETI et al. 2016) kb. 3 naponta az időjárástól függően (Leány-kúti rét: medián: 3; terjedelem: 2-6 nap; Hegyesd: medián: 3; terjedelem: 1-5 nap). A mintavételt legkésőbb a lepkék repülési időszakának második napján kezdtük és legkorábban a repülési időszak vége előtt két nappal fejeztük be. A mintavétel során körülbelül egy óra alatt körbejártuk a teljes rétet, feljegyeztük az éppen virágzó rovarporozta növényfajokat és becsültük a kinyílt, nem hervadt virágok gyakoriságát. A teljes rét fajonkénti virággyakoriság-becslésére a következő, egymástól egyenlő távolságú kategóriákat használtuk: nagyon ritka, ritka, többé-kevésbé ritka, többé-kevésbé gyakori, gyakori, nagyon gyakori. 


\section{Nektárnövény tulajdonságok}

A nektárnövényfajok közötti választás megértéshez a kis apollólepkék szempontjából fontosnak tünő virágtulajdonságokról gyüjtöttünk adatokat a Biolflor (KLOTZ et al. 2002) adatbázisból. Ezek a következőek: (1) a rovarbeporzás jelentősége (kategóriás változó: ritkán, közepesen gyakran, általában, mindig, ismeretlen), (2) nektárjuttatás mennyisége (kategóriás: semmi, kevés, közepes, sok, ismeretlen), (3) virágszerkezet (Kugler-féle virágtípus; kategóriás: korong alakú, mély pártacsövü korong alakú, pillangós, ajakos, fészkes, pollen-/szélporozta, egyéb: eredetileg 3 kategóriába tartozó 9 fajt soroltunk ebbe a csoportba; (KUGLER 1970)), (4) virágszín (kategóriás: fehér, kék, rózsaszín, lila [az adatbázis „violet” és ,purple” megnevezéseit egyaránt lilaként használva összevontuk], piros, sárga, barna, zöld). Azon fajok esetében, amelyekröl nem találtunk adatot, a nemzetség többi fajához tartozó adatok közül a legvalószínübbet vagy a leggyakrabban előfordulót használtuk.

\section{Adatelemzés}

Arra voltunk kíváncsiak, hogy a virágfajonkénti látogatási arányokkal milyen növényi tulajdonságok függenek össze, hogy ebből következtethessünk a növényfajok közötti választást befolyásoló tényezőkre. A viráglátogatási megfigyeléseket évekre összegeztük, majd növényfajonkénti százalékos viráglátogatási arányokat számoltunk. Egy-egy lepkeegyedröl több viráglátogatási megfigyelést is gyüjthettünk, az összes éves megfigyelést összegeztük, nem súlyozva azzal, hogy mely egyedekröl származnak a megfigyelések. Kiszámoltuk a virággyakoriságok évenkénti és növényfajonkénti mediánját. A virággyakoriságot kategóriás változóként használtuk az elemzések során.

Válaszváltozónk a növényfajonkénti viráglátogatási arányok $\log _{10}(\mathrm{x}+0,1)$ transzformáltja volt. Az összes lehetséges magyarázó változó a virággyakoriság, az év, a rovarbeporzás szerepe, a nektárjuttatás mennyisége, a Kugler-féle virágtípus és a virág színe voltak. A két helyszín adatait külön-külön elemeztük. A magyarázó változók közül véletlen erdők (,random forest”, STROBL et al. 2007) módszerrel választottuk ki a viráglátogatással összefüggő fontosabb változókat. Az így kapott változók viráglátogatásra gyakorolt hatásának és a köztük található kapcsolatokat döntési fákkal („,decision tree”) elemeztük tovább. A döntési fa olyan módszer, amely grafikusan megmutatja a célváltozók és magyarázó változók közötti összefüggéseket, valamint a magyarázó változók hatásai közti hierarchiát (DE’ATH \& FABRICIUS, 2000). E módszerek korlátja, hogy nem tudják figyelembe venni azt, hogy - mint esetünkben is - egyes lepkeegyedek többször is szerepelnek az adatsorban. Munkánk feltáró elemzés, eredményeink ennek ismeretében értelmezhetőek.

Az elemzéseket és az ábrákat R 3.6.3 statisztikai környezetben (R Core Team 2018) készítettük. A ,party 1.3-4” csomagot (HOTHORN et al. 2006) használtuk a véletlen erdők és a döntési fa elemzéshez. 


\section{Eredmények}

A Leány-kúti réten 5 év alatt 524 egyed 2676, míg a Hegyesden 2 év alatt 234 egyed 2552 viráglátogatását figyeltünk meg.

A Leány-kúti réten a talált 71 rovarporozta növényfaj közül 36-on egyszer sem figyeltünk meg kis apollólepkéket; 18 fajt pedig 1\%-nál ritkábban látogattak, míg 17 fajt 1\%-ban, vagy annál nagyobb arányban látogattak valamelyik évben; Hegyesden 75 növényfaj közül 44-et elkerültek, 24 fajon 1\%-nál ritkábban táplálkoztak, 7 fajon figyeltük meg őket legalább 1\%-ban (fajlista: Melléklet: 1 táblázat). A repülési időszakonkénti látogatási arány jelentősen változott növényfajok között (min-max: 0-60,4\% (Leány-kúti rét), 0-73,6\% (Hegyesd)). Az évente négy leggyakrabban látogatott faj összesített látogatási aránya 76,4$84,8 \%$ volt a Leány-kúti réten, illetve $89,2-92,8 \%$ Hegyesden (Melléklet: 1. táblázat). Az öt vizsgálati év során hét növényfaj közül került ki az adott évben leggyakrabban látogatott négy faj a Leány-kúti réten, melyek a következök: erdei gyöngyköles (Aegonychon purpurea-coeruleum), magyar szegfü (Dianthus giganteiformis subsp. pontederae), csattogó szamóca (Fragaria viridis), üstökös pacsirtafü (Polygala comosa), enyves szegfü (Silene viscaria), közönséges kakukkfü (Thymus odoratissimus), hegyi here (Trifolium montanum); a Hegyesden két év alatt öt növényfaj alkotta az évente leggyakrabban látogatott négy faj csoportját: erdei gyöngyköles, közönséges ínfü (Ajuga genevensis), magyar szegfü, enyves szegfü, kaszanyüg bükköny (Vicia cracca). Az évente leggyakrabban látogatott faj látogatási aránya 36,5-60,4\% között változott a Leány-kúti réten és 70,3-73,6\% között a Hegyesden. A kis apollólepkék a Leány-kúti réten leggyakrabban a magyar és az enyves szegfüvet, míg a Hegyesden mindkét évben a magyar szegfüvet látogatták (Melléklet: 1. táblázat). A Hegyesden kevesebb fajt látogattak nagy arányban, mint a Leány-kúti réten (Melléklet: 2. táblázat).

Nagy változatosságot találtunk az évek és a rétek között a virágok elöfordulásában és a látogatási arányokban a virágok színe és szerkezete szerint (1. ábra). A kis apollólepkék növényfajok közötti választását a véletlen erdők alapján mindkét réten befolyásolta a virággyakoriság és a virág színe, a Leány-kúti réten kisebb mértékben a virágok szerkezete és a rovarbeporzás jelentősége (2. ábra). A döntési fák segítségével e változók közötti hierarchiát is megérthetjük: a kis apollólepkék a Leány-kúti réten a nem túl ritka virágok közül gyakrabban táplálkoztak a lila és piros, a Hegyesden a kék, lila és piros virágúakon, mint a más színüeken. A ritka fajok esetében a párta színe kimutatható mértékben befolyásolta a választást (3-4. ábra). A Leány-kúti réten a nem túl ritka piros és lila virágú fajokat gyakrabban látogatták, ha a virágok pillangósok vagy mély csövű korong alakúak voltak, ritkábban, ha sekély korong alakúak vagy ajakosok (1. ábra). A nagyon ritkán előforduló fajok közül gyakrabban táplálkoztak olyanokon, amelyeknél a rovarok jelentősége a beporzásban kizárólagos. Sem a virágok szerkezete, sem a rovarbeporzás jelentősége nem befolyásolta kimutathatóan a hegyesdi kis apollólepkék nektárforrás-választását, a nektártermelés menynyisége pedig egyik réten sem játszott szerepet a választásban és a különböző években e mintázatok hasonlóak voltak (3-4. ábra). 


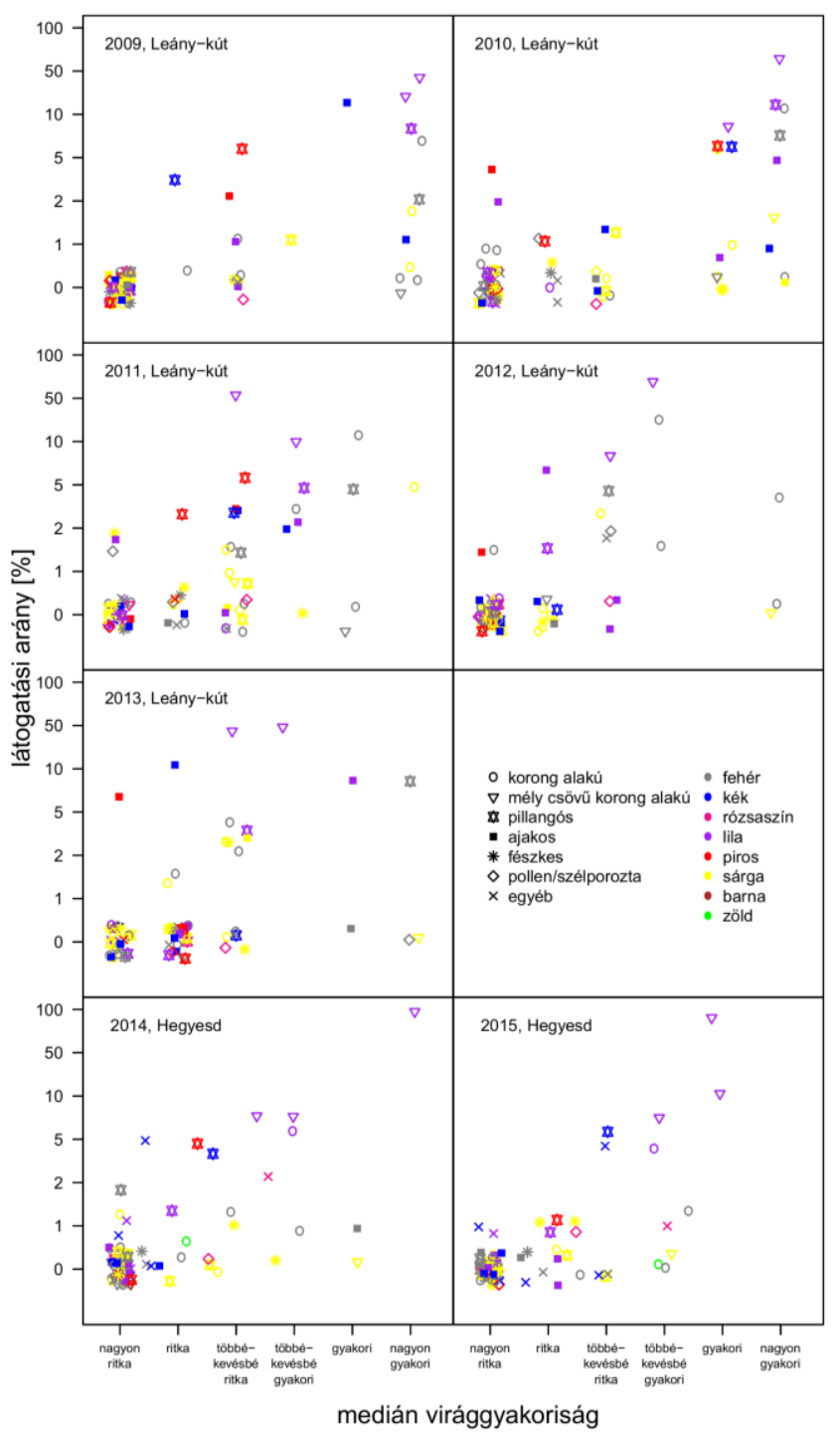

1. ábra: Kis apollólepkék évenkénti viráglátogatási arányai (\%) és a virággyakoriságok a két réten. Mindegyik szimbólum egy-egy növényfajt jelent. A szimbólum típusa a növényfaj virágtípusát (KUGLER 1970), színei a virágok színét jelentik, kivéve a fehér virágokat, amiket az ábrán szürkével jelöltünk. A pontokat mindkét tengely mentén kis mértékben megszórtuk a jobb láthatóság kedvéért. Az y-tengely 10-es alapú logaritmus-skálájú.

Figure 1: Clouded Apollo butterflies' annual flower visit ratios (\%; on y-axis) and flower abundances at the two study sites. Each symbol represents a flower species. Symbol shapes represent floral structures: $\circ$ disc flower, $\nabla$ stalk disk flower, flag blossom, - lip flower, * flower head, $\diamond$ pollen/wind pollinated flowers, $\times$ other types (KUGLER 1970). Symbol colours denote petal colours, except in white flowers represented here with grey. On the $\mathrm{x}$-axis, from left to right, flower abundance increases (very scarce $\rightarrow$ very abundant). We jittered symbols on both axes for better visibility. The $y$-axis is $\log _{10}$-scaled. 


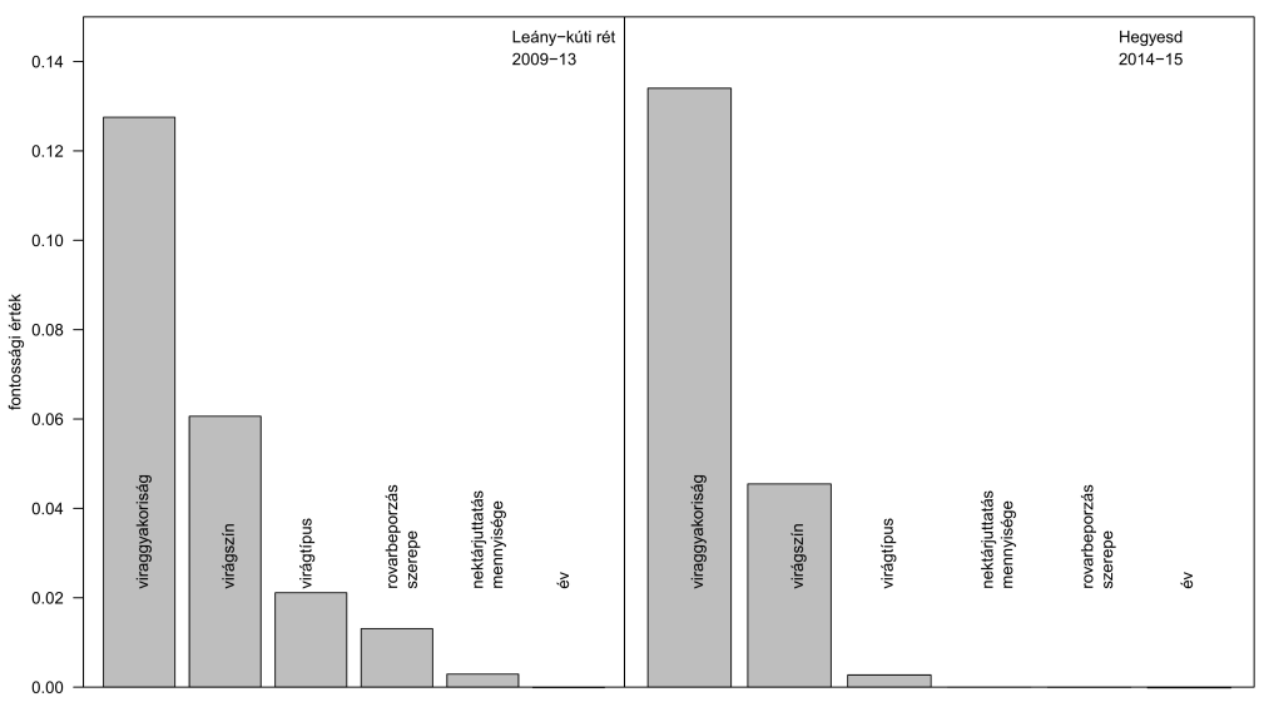

2. ábra: A viráglátogatás arányát magyarázó változók fontossági sorrendje a véletlen erdők szerint, évekre összesítve a két réten.

Figure 2: Explanatory variables' importance in flower visit ratios according to the random forests, pooled for years at the two study sites. Variables from left to right: flower abundance, flower colour, flower type (see symbols on Fig. 1), role of insect pollination, nectar reward, year.

\section{Értékelés}

A kis apollólepkék egy-másfél hónapos repülési időszaka alatt a vizsgált két kis területủ élöhelyen összesen 71 (Leány-kúti rét), illetve 75 (Hegyesd) rovarporozta növényfajt találtunk. Ehhez hasonló a közép-európai természetes rétek rovarporozta virágos növényeinek sokfélesége is (BINKENSTEIN et al. 2013; HEJCMAN et al. 2013). A Hegyesden kevesebb fajból táplálkoztak a lepkék nagy arányban, mint a Leány-kúti réten, feltehetőleg a vizsgált évek során kiemelkedően magas magyar szegfü abundancia miatt. A hegyesdi viráglátogatások több mint 70\%-át ezen a fajon figyeltük meg. Hasonlóan nagy arányban látogatott faj a Leány-kúti réten nem volt, ott évenként 4 fajon figyeltük meg a látogatások több mint $80 \%$-át, és a négy faj közül egyiknek sem volt kiemelkedő a látogatottsága a másik háromhoz képest. A viráglátogatási mintázat mindkét élőhelyen arra utal, hogy a lepkék választanak forrásaikból, és a két rét közötti különbség azt sugallja, hogy a válogatás mértéke környezetfüggő. Környezetfüggőségre utal az is, hogy mindkét réten a virággyakoriság volt a legfontosabb látogatást befolyásoló nektárforrás-jellemző.

A kis apollólepkék növényfajok közötti választását mindkét réten meghatározta a virággyakoriság, a virágszín alapján választottak a gyakoribb fajokból, de a szín nem játszott szerepet a ritka növényfajok látogatásában (3-4. ábra). A Leány-kúti réten a gyakoribb piros és lila virágú fajok esetében a virágok szerkezete is befolyásolta a választást, a különö- 
sen ritka fajok esetében pedig a rovarbeporzás jelentősége (3. ábra). Sem a virágok szerkezete, sem a rovarbeporzás jelentősége nem befolyásolta kimutathatóan a hegyesdi kis apollólepkék nektárforrás-választását (4. ábra). Valószínü, hogy a Hegyesden a magyar szegfü rendkívüli gyakorisága és térbeli homogenitása következtében kialakult magas, több mint 70\%-os látogatási arány, valamint az, hogy a többi, viszonylag gyakran fogyasztott növényfaj virága szintén lilás színủ és hosszú pártájú volt, elfedte a virágszerkezet hatását. Noha a virággyakoriság volt a kis apollólepkék látogatását befolyásoló legfontosabb változó, néhány gyakori növényt egyáltalán nem látogattak, ilyen pl. a Leány-kúti réten a fehér pártájú pusztai sárma (Ornithogalum orthophyllum subsp. kochii), míg a legtöbbet látogatottak közül számos faj csak közepes gyakorisággal fordult elö (1. ábra; Melléklet: 1. táblázat). Valószínü, hogy az energiabefektetés-arányosan kinyerhetö legtöbb és/vagy legjobb nektárt nyúitó fajokat látogatták a leggyakrabban, és valószínüleg vannak olyan növényfajok, amelyek alkalmatlan nektárforrások a kis apollólepkék számára.

A virággyakoriság durva becslése a ténylegesen elérhető táplálék mennyiségének, mivel csak a virágmennyiségről ad információt, a nektár mennyiségéről és minőségéről nem. A nektár mennyisége az elemzéseink szerint nem volt fontos változó (2. ábra). Ennek lehetséges oka, hogy nem aktuális, vizsgálati helyszíneken mért, hanem adatbázisból származó, durva felbontású kategóriás változókat használtunk. Valószínünek tartjuk, hogy az aktuálisan elérhető, a viráglátogatók által intenzíven mintavételezett nektármennyiségek kapcsolatban állnak a nektárforrás-választással (VAN RIJN \& WÄCKERS 2016). A nektármennyiséget sok környezeti tényezö befolyásolja, ezért fajok közötti változatossága magas lehet (WITT et al. 1999). SzIGETI (2018) alapján a magyar és az enyves szegfü kivételével a gyakran látogatott növényfajok esetén nagy volt azon virágok száma, melyek nem tartalmaztak nektárt, ami azt sugallja, hogy a kis apollólepkék gyakran próbálnak táplálkozni olyan fajokon, amelyek nem, vagy csak nagyon kis mennyiségben tartalmaznak táplálékot. A nektármennyiségeket részletesen is figyelembe vevő elemzésekhez a korábbiaknál jóval nagyobb intenzitású terepi mintavételre volna szükség (SZIGETI 2018).

Vizsgálatunkban a kis apollólepkék által leglátogatottabb virágfajok kékek, lilák vagy pirosak (3-4. ábra). KUDRNA \& SEUFERT (1991) nem találtak színpreferenciát kis apollólepkéknél, míg VAN SWAAY et al. (2010) piros és lila, VOJNITS \& ÁCS (2000) lila és mályva színú virágok, PECSENYE (2017) pedig bíbor és lila színű ajakosok (Lamiaceae) gyakori látogatását figyelték meg. Más lepkefajok, pl. a rokon Parnassius smintheus DOUBLEDAY, 1847 sárga (MATTER et al. 2009), illetve egyes boglárkalepkék (Lycaenidae) sárga és ibolya, más boglárkák föleg sárga virágokat látogatnak (BĄKOWSKI \& BOROŃ 2005; PECSENYE 2017). Az adatbázisból vett színkategóriák az emberi látás alapján készültek és a különböző források eltérő szín-elnevezéseket használtak. A virágok színe függhet a termőhelytől is, így egy nemzetközi adatbázisból származó adatsor egy konkrét élőhelyre nézve torzíthat. Például a Hegyesden gyakori és látogatott bérci here (Trifolium alpestre) a Biolflor adatbázis szerint piros, ezt a fajt mi inkább lilásrózsaszínnek mondanánk. Az alábbiakban mutatunk néhány példát a Leány-kúti réten, illetve a Hegyesden előforduló növényfaj Biolflor adatbázisban talált a színére: fehér: Fragaria viridis, Trifolium montanum, kék: Ajuga genevensis, Vicia cracca, rózsaszín: Thymus odoratissimus, lila: Aegonychon purpurea-coeruleum, Dianthus giganteiformis subsp. pontederae, Silene viscaria, piros: Trifolium alpestre, T. pratense. Az UV-tartományban is látó lepkék másként érzékelik a színeket hozzánk képest (ARIKAWA 2003), ezért érdemes lenne a lepkék 
látásának figyelembevételével, hasonló napsugárzási intenzitás mellett, in situ spektrofotometriás méréseket végezni a virágszínek objektív meghatározásához. Szemben a méhalkatúak (Apoidea) többségével (PEITSCH et al. 1992), a lepkefajok látása jelentősen eltérhet egymástól (EGUCHI et al. 1982). A Parnassius nemből a P. glacialis BUTLER, 1866 látásáról vannak ismereteink (AWATA et al. 2010). Ez a faj a kis apollólepkék közeli rokona (MICHEL et al. 2008, ОмОТО et al. 2009), így elképzelhetö, hogy látásuk is hasonló, és a $P$. glacialis látásának ismeretében hitelesebb képet kaphatnánk arról, hogyan érzékelik a kis apollók a látogatott virágok színét.

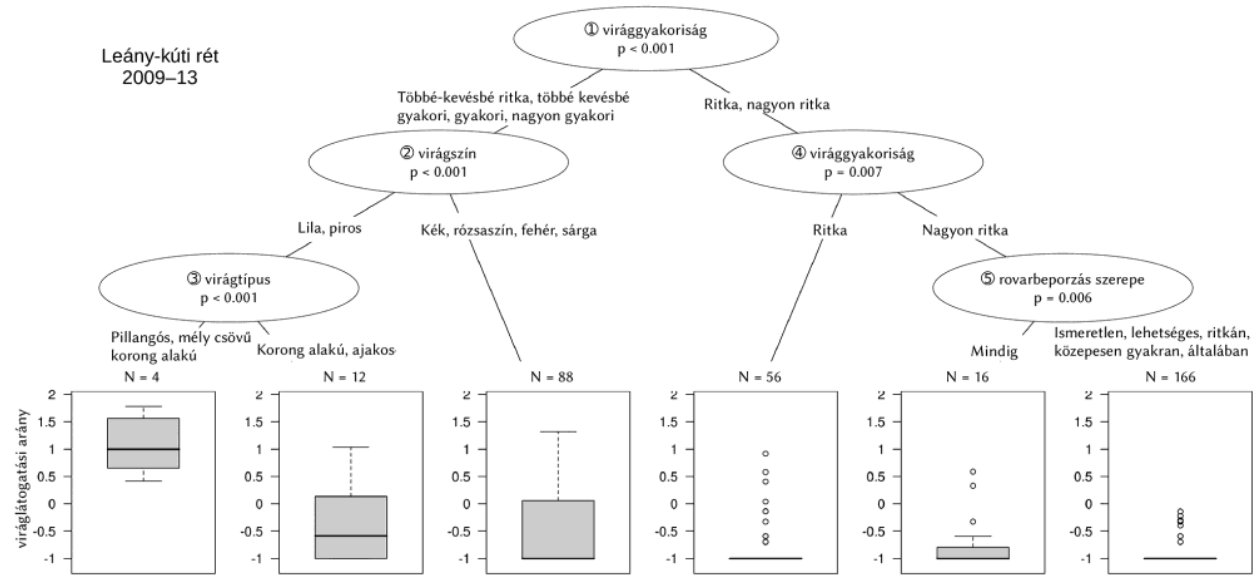

3. ábra: A viráglátogatásra ható tényezők döntési fa alapján a Leány-kúti réten, évekre összesítve. Az ellipszisek a csomópontok, azt mutatják, hogy a magyarázó változó alapján hol lehet szignifikánsan kettébontani a válaszváltozót gyakrabban és ritkábban látogatott csoportokra. A bekarikázott számok csomópont azonosítók. Az élek feliratai jelzik, hogy a magyarázó változók milyen értékei mentén különültek el a szétválasztott csoportok. A dobozábrák mutatják a viráglátogatási arányokat, ahol az y-tengely 10-es alapú logaritmus-skálájú, és N jelöli a növényfajok számát; a növényfajok évente ismétlődnek az elemzésben.

Figure 3: Floral traits influencing visits ratios at Leány-kúti rét, years pooled. The ellipses are the nodes showing where explanatory variables split the response variable, visit ratio, into two groups, i.e. more and less frequently visited. Circled numbers are node identifiers. Edge labels show split values of the response variables. Box-plots show the flower visit patterns; their $\mathrm{y}$-axis is $\log -10$-scaled, $\mathrm{N}$ is the number of flower species; plant species included in the analyses are annually repeated. The variables responsible for splits are, in node 1 and node 4: flower abundance (1 left: more or less abundant - very abundant, right: scarce, very scarce; 4 left: scarce, right: very scarce), node 2: flower colour (left: purple, red; right: blue, pink, white, yellow), node 3: flower structure (left: flag blossom, stalk disk, right: disk, lip flower) and node 5: importance of insect pollination (left: exclusive, right: facultative).

Valószínüleg a növényfajok közötti választás nem magyarázható csupán a virágok gyakoriságával és színével. Egyszerre több tényező is befolyásolhatja azt, és egyes tényezők egymással is összefügghetnek, a szerkezet és a szín nem függetleníthető: pl. a kék, lila, piros fajok legtöbbször egyben mély kelyhüek, és több nektárt termelnek (GALETTO \& BERNARDELLO 2004; RODRÍGUEZ-GIRONÉS \& SANTAMARÍA 2004; NEUMAYER \& SPAETHE 2007). 


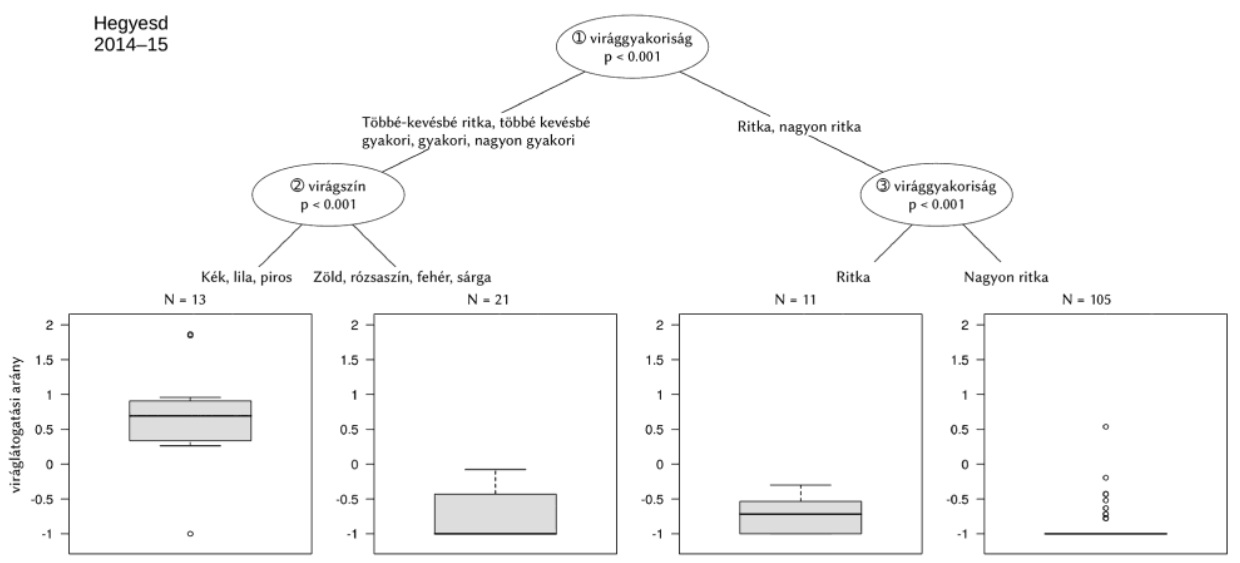

4. ábra: A viráglátogatásra ható tényezők döntési fa alapján a Hegyesden, évekre összesítve. Az ellipszisek a csomópontok, azt mutatják, hogy a magyarázó változó alapján hol lehet szignifikánsan kettébontani a válaszváltozót gyakrabban és ritkábban látogatott csoportokra. A bekarikázott számok csomópont azonosítók. Az élek feliratai jelzik, hogy a magyarázó változók milyen értékei mentén különültek el a szétválasztott csoportok. A dobozábrák mutatják a viráglátogatási arányokat, ahol az ytengely 10-es alapú logaritmus-skálájú, és N jelöli a növényfajok számát; a növényfajok évente ismétlődnek az elemzésben.

Figure 4: Floral traits influencing visits ratios at Hegyesd, years pooled. The ellipses are the nodes showing where explanatory variables split the response variable, visit ratio, into two groups, i.e. more and less frequently visited. Circled numbers are node identifiers. Edge labels show split values of the response variables. Box-plots show the flower visit patterns; their $\mathrm{y}$-axis is $\log _{10}$-scaled, $\mathrm{N}$ is the number of flower species; plant species included in the analyses are annually repeated. The variables responsible for splits are, in node 1 and node 3 : flower abundance ( 1 left: more or less abundant - very abundant, right: scarce, very scarce; 3 left: scarce, right: very scarce) and node 2: flower colour (left: blue, purple, red; right: green, pink, white, yellow).

A növényfajok közti választás mértéke hasonló volt más lepkefajokéhoz (JENNERSTEN 1984; BAZ 2002; MATTER et al. 2009; HANTSON \& BAZ 2013). A viráglátogatás populációs, évek közötti és egyedszintű étrendbeli különbségeiben, valamint az élőhelyen belüli elöfordulás alakításában fontos szerepet tölt be a virággyakoriság tér- és időbeli változása (SzIGETI et al. 2015). Élöhelyek és populációk között is lehetnek eltérések az imágók étrendjében. Ezt részben a két általunk vizsgált hasonló méretü, egymáshoz közeli élőhely (Melléklet: 1. táblázat), részben pedig más közleményekben (KUDRNA \& SEUFERT 1991; VAN HELSDINGEN et al. 1996; VOJNITS \& ÁCs 2000; KONVIČKA et al. 2001; KONVIČKA et al. 2006; LARA RUIZ 2011) ismertetett, kis apollólepkék látogatta nektárforrások eltérései támasztják alá. Az általunk vizsgált két rét rovarporozta növényeinek jelentős része azonos, abundanciáik azonban nagymértékben különböznek, pl. a magyar szegfü sokkal ritkább a Leány-kúti réten, mint a Hegyesden. A kis apollólepkék táplálkozásának egyedi nyomon követéses vizsgálata kimutatta, hogy a virágokon eltöltött kezelési (azaz a leszállás és a táplálkozás megkezdése közötti) és táplálkozási időtartamok hasonlóak a leggyakrabban látogatott növényfajok többségénél (GóR 2017). Ezen fajok profitabilitása (azaz, hogy mennyi- 
re éri meg egy lepkének táplálkozni a virágon, annak függvényében, hogy mennyi időt, energiát kell fordítania a virág megtalálására, a nektár kinyerésére, ahhoz képest, hogy mennyi tápanyaghoz és energiához juthat a látogatott virágból) hasonló (GóR 2017), noha e vizsgálat még nem számol azzal, hogy a vizsgált fajok között annak a valószínűsége, hogy egy virág tartalmaz-e nektárt, jelentősen eltérhet (SZIGETI et al. 2018). Hasonló profitabilitású fajok pedig a táplálkozó lepkék szempontjából lehetnek felcserélhető források, amelyekből mindegy, hogy egy adott időszakban és élöhelyen melyik fordul elö, feltéve, hogy valamelyik elérhetö. A kis apollólepkék különböző élőhelyein talált nagyon eltérő nektárforrások ismeretében jelen vizsgálatunk érvényessége a két rétre korlátozott, általánosításokhoz jóval több, eltérő éghajlatú rét vizsgálata volna szükséges.

A viráglátogató rovaroknak érdemes választaniuk a rendelkezésükre álló széles kínálatból, érdemes tér- és időbeli megjelenésüket forrásaikhoz igazítaniuk, valamint meg kell tanulniuk a virágok kezelését, mivel felnőttkori táplálkozásuknak jelentős hatása lehet rátermettségükre (fitneszükre) (GOULSON 1999; STEPHENS et al. 2007; ERHARDT \& MEVISCHÜTZ 2009), így a hatékonyabban táplálkozó egyedek elönybe kerülnek kevésbé hatékony fajtársaikkal szemben.

A kis apollólepkék állományai Európa-szerte csökkennek, kivéve Észtországban, ahol elterjedési területük növekedett (LIIVAMÄGI et al. 2013). Hazánkból 2080-ra akár ki is pusztulhat a táj és a klíma változása miatt (PARMESAN et al. 1999; SETTELE et al. 2008). A növény-beporzó rendszerek az emberi hatásoknak különösen kitett és emiatt sebezhetö közösségek (POTTS et al. 2010; BURKLE et al. 2013; NILSSON et al. 2013). Sebezhetöségüket saját kutatómunkánk során is tapasztaltuk: két kis méretủ élőhelyen végeztük vizsgálatainkat. Ezek egyikén, a Leány-kúti réten a kis apollólepke állománya drasztikusan lecsökkent 2013-ra, emiatt volt szükséges a kutatások másik területen, a Hegyesden való folyatására. Azt tapasztaltuk, hogy az egyedszámok mellett a táplálkozó egyedek aránya is csökkent. Ezzel ellentétben az elérhető és a látogatott fajok száma és azok virágmennyisége nem mutatott jelentős csökkenést az öt vizsgálati év alatt. Az egyedszámban tapasztalható csökkenést véleményünk szerint a terület beerdősülése okozhatta, mivel az erdőszegélyben csökkentek a kora tavasszal nyíló, keltikét (lárvális tápnövény) tartalmazó területek (SZIGETI 2018), ahol a hernyók és a bábok jól tudnak fejlődni (VALIMAKI \& ITAMIES 2005). Emellett a tavaszi geofitonok eltünésének oka lehet más, az erdőhasználatban bekövetkezett változás is, mint pl. a fafajok összetételének átalakulása (KONVIČKA \& KURAS 1999). A kis apollólepkék lárvaként monofágok (MEGLÉCZ et al. 1997), imágóként a táplálékspektrumuk szük, mivel néhány növényfajt látogatnak csak nagy arányban. Ezek a jellemzők is magyarázhatják védettségét (Berni Egyezmény; VAN SwAAY et al. 2010). Ahhoz, hogy egy élőhely megfelelő legyen egy adott lepkefaj számára, meghatározó a lárvális tápnövény jelenléte, de az egyéb források, köztük a felnőtt lepkék táplálékát biztosító nektárnövények jelenléte is lehet nélkülözhetetlen (ERHARDT \& MEVI-SCHÜTZ 2009), mivel sok faj esetében a lárva- és a felnőttkori táplálék együttesen biztosítja a megfelelő mennyiségü és elegendően változatos fehérje-, szénhidrát- és ásványianyag-forrásokat (ERHARDT \& MEVISCHÜTZ 2009). A kis apollólepkék számára a mozaikos élőhelyek kedvezőek: ahol egymáshoz közel találhatóak nyílt (gyeppel borított, nektárforrást, napozóhelyet nyújtó) és zárt foltok (erdős terület, amelynek aljnövényzetében a lárvális tápnövény előfordul; hazánkban az odvas és az ujjas keltike erdőkben virágzik még a lombfakadás elött, de a kis apollólepkék repülési időszakára a lombkorona záródik, a keltikék hajtásai pedig gyakran 
már elszáradnak; más élőhelyeken keltikefajok nőhetnek nyílt gyepekben is) (VALIMAKI \& ITAMIES 2005; LIIVAMÄGI et al. 2013; SzIGETI, 2015). E mozaikosság a fontos nektárforrások hosszú távú biztosításában is szerepet játszhat, hiszen az együtt járhat a nektárforrások heterogenitásával: amennyiben egyes források pl. időjárás hatására bizonyos években nem jelennek meg a lepkéknek szükséges mennyiségben, hasonló értékü források pótolhatják azokat. A kis apollólepke populációit veszélyeztető tényezőket érdemes volna feltárni, azokat a jövőben megszüntetni és a populációik fennmaradását segítő kezelési stratégiákat kidolgozni, valamint érdemes lenne egy fajmegörzési tervet készíteni, mint ahogy a díszes tarkalepke (Euphydryas maturna (LINNAEUS, 1758)) esetében is történt (VARGA 2006). A megfelelő védelmi stratégiák kialakításához elengedhetetlen, hogy részleteiben ismerjük egy faj ökológiáját (BERGSTRÖM 2005; LUOTO et al. 2008). A fentiek alapján úgy gondoljuk, hogy a lárvális tápnövény mellett érdemes figyelmet fordítani a lehetséges nektárforrások, elsősorban közepesen mély (8-12 mm), lila, piros, kék és rózsaszín virágú növényfajok megőrzésére, a faj- és élőhelyvédelmi tervek kidolgozása során.

Vizsgálatunkban kimutattuk, hogy a kis apollólepkék választanak a rendelkezésükre álló növényfajokból; néhányat nagy arányban, számos további fajt alkalmanként látogatnak, és sokat elkerülnek, akár nagy gyakoriságuk ellenére is. A kis apollólepkék esetében a nektárnövényfajok közötti választást leginkább a növényfaj gyakorisága, valamint a virág színe és típusa határozza meg, de feltehetően egyéb, eddig még nem vizsgált tényezők is szerepet játszanak a választásban.

Köszönetnyilvánítás. Köszönjük a terepi mintavételben nyújtott segítségét KöRÖSI ÁDÁMnak és az ÁTE Biológia BSc és Biológus MSc szakos hallgatóinak. Az ÁTE Doktori Iskolája biztosította Sz.V. és V.F. PhD ösztöndíjait a terepi mintavétel, valamint a kézirat megírása során. Köszönjük az ÁTE által biztosított NKB pályázatokat, melyek anyagi támogatást jelentettek 2018-ban és 2019ben (témaszámok: 2018/007819, KEDH106320). A Természetvédelmi Hatóság engedélye KTF: 28512/2010, 31430/2014. Az elemzésekhez és a kézirat elkészítéséhez szabad és szabadon felhasználható szoftvereket alkalmaztunk (LibreOffice, Mendeley, R, RKWard; Ubuntu-környezetben). Köszönjük Prof. HoRnUng ERZSÉBET, Prof. VARGA ZOLTÁN és egy névtelen bíráló hasznos gondolatait és megjegyzéseit. 


\section{Irodalomjegyzék}

ABRol D. P. 2012. Pollination biology - Biodiversity conservation and agricultural production. Springer Netherlands, Dordrecht. 823 pp.

Albrecht M., Duelli P., Müller C., Kleijn D. \& Schmid B. 2007. The Swiss agri-environment scheme enhances pollinator diversity and plant reproductive success in nearby intensively managed farmland. Journal of Applied Ecology 44: 813-822. https://doi.org/10.1111/j.13652664.2007.01306.x

ANDERSSON S. 2003. Foraging responses in the butterflies Inachis io, Aglais urticae (Nymphalidae), and Gonepteryx rhamni (Pieridae) to floral scents. Chemoecology 13: 1-11. https://doi.org/10.1007/s000490300000

ARIKAWA K. 2003. Spectral organization of the eye of a butterfly, Papilio. Journal of Comparative Physiology 189: 791-800. https://doi.org/10.1007/s00359-003-0454-7

Awata H., Matsushita A., Wakakuwa M., Arikawa K. 2010. Eyes with basic dorsal and specific ventral regions in the glacial Apollo, Parnassius glacialis (Papilionidae). Journal of Experimental Biology 213: 4023-4029. https://doi.org/10.1242/jeb.048678

BAKER H. G. \& BAKER I. 1983. Floral nectar sugar constituents in relation to pollinator type. In Jones C. E. \& LitTle T. J. (ed.): Handbook of experimental pollination biology. Van Nostrand Reinhold, New York, pp. 117-141.

BĄKOWSKI M. \& BoROŃ M. 2005. Flower visitation patterns of some species of Lycaenidae (Lepidoptera). Biological Letters 42: 13-19. http://www.biollett.amu.edu.pl

BAZ A. 2002. Nectar plant sources for the threatened Apollo butterfly (Parnassius apollo L. 1758) in populations of central Spain. Biological Conservation 103: 277-282. https://doi.org/10.1016/S0006-3207(01)00138-0

BERgSTRÖM A. 2005. Oviposition site preferences of the threatened butterfly Parnassius mnemosyne - Implications for conservation. Journal of Insect Conservation 9: 21-27. https://doi.org/10.1007/s10841-004-3204-4

Binkenstein J., Renoult J. P. \& Schaefer H. M. 2013. Increasing land-use intensity decreases floral colour diversity of plant communities in temperate grasslands. Oecologia 173: 461-471. https://doi.org/10.1007/s00442-013-2627-6

Blackiston D., Briscoe A. D. \& Weiss M. R. 2011. Color vision and learning in the Monarch Butterfly, Danaus plexippus (Nymphalidae). Journal of Experimental Biology 214: 509-520. https://doi.org/10.1242/jeb.048728

Bloch D., Werdenberg N. \& ERhardt A. 2006. Pollination crisis in the butterfly-pollinated wild carnation Dianthus carthusianorum? New Phytologist 169: 699-706. https://doi.org/10.1111/j.1469-8137.2006.01653.x

BogGS C. L. 1997. Reproductive allocation from reserves and income in butterfly species with differing adult diets. Ecology 78: 181-191. https://doi.org/10.1890/00129658(1997)078[0181:RAFRAI]2.0.CO;2

BogGs C. L. \& FREEMAN K. D. 2005. Larval food limitation in butterflies: Effects on adult resource allocation and fitness. Oecologia 144: 353-361. https://doi.org/10.1007/s00442-005-0076-6

O’Brien D. M., Boggs C. L., Fogel M. L., 2004. Making eggs from nectar: The role of life history and dietary carbon turnover in butterfly reproductive resource allocation. Oikos 105: 279-291. https://doi.org/10.1111/j.0030-1299.2004.13012.x 
Burkle L. A., Marlin J. C. \& Knight T. M. 2013. Plant-pollinator interactions over 120 years: Loss of species, co-occurrence and function. Science 339: 1611-1615. https://doi.org/10.1126/science. 1232728

CAHENZLi F. \& ERHARDT A. 2013. Nectar amino acids enhance reproduction in male butterflies Oecologia 171: 197-205. https://doi.org/10.1007/s00442-012-2395-8

CONNER J. K., DAvis R. \& RUSH S. 1995. The effect of wild radish floral morphology on pollination efficiency by four taxa of pollinators. Oecologia 104: 234-245. https://doi.org/10.1007/BF00328588

Cini A., Barbero F., Bonelli S., Bruschini C., Casacci L. P., Piazzini S., Scalercio S. \& DaPPORTO L. 2020. The decline of the charismatic Parnassius mnemosyne (L.) (Lepidoptera: Papilionidae) in a Central Italy national park: a call for urgent actions. Journal of Insect Biodiversity 16: 47-54. https://doi.org/10.12976/jib/2020.16.2.2

CORY J. S. \& Goulson D. 1993. Flower constancy and learning in foraging preferences of the green veined butterfly- Pieris napi. Ecological Entomology 18: 315-320. https://doi.org/10.1111/j.1365-2311.1993.tb01107.x

Curtis R. J., Brereton T. M., Dennis R. L. H., Carbone C. \& IsaAC N. J. B. 2015. Butterfly abundance is determined by food availability and is mediated by species traits. Journal of Applied Ecology 52: 1676-1684. https://doi.org/10.1111/1365-2664.12523

DE’ATH G. \& FABRicius K. E. 2000. Classification and regression trees: A powerful yet simple technique for ecological data analysis. Ecology 81: 3178-3192. https://doi.org/10.1890/00129658(2000)081[3178:CARTAP]2.0.CO;2

DENNIS R. L. H. 2010. A resource-based habitat view for conservation: butterflies in the British landscape. John Wiley \& Sons, Ltd., Chichester, 420 pp. https://doi.org/10.1002/9781444315257

Dicks L. V., Abrahams A., Atkinson J., Biesmeijer J., Bourn N., Brown C. \& Sutherland W. J. 2013. Identifying key knowledge needs for evidence-based conservation of wild insect pollinators: a collaborative cross-sectoral exercise. Insect Conservation and Diversity 6: 435-446. https://doi.org/10.1111/j.1752-4598.2012.00221.x

Eguchi E., Watanabe K., Hariyama T. \& Yamamoto K. 1982. A comparison of electrophysiologically determined spectral responses in 35 species of Lepidoptera. Journal of Insect Physiology 28(8): 675-682. https://doi.org/10.1016/0022-1910(82)90145-7

Elzinga J. A., Atlan A., Biere A., Gigord L., Weis A. E. \& Bernasconi G. 2007. Time after time: flowering phenology and biotic interactions. Trends in Ecology \& Evolution 22: 432-439. DOI: https://doi.org/10.1016/j.tree.2007.05.006

ERHARDT A. 1991. Nectar sugar and amino-acid preferences of Battus philenor. Ecological Entomology 16: 425-434. https://doi.org/10.1111/j.1365-2311.1991.tb00235.x

ERhardt A. \& Mevi-SchÜtz J. 2009. Adult food resources in butterflies. In: Settele J., Shreeve T., KONVIČKA M. \& DYCK H. vaN (ed.): Ecology of European butterflies. Cambridge University Press, pp. 9-16.

FARKAS Á., MolnÁr R., MorschHAUSER T. \& HAHN I. 2012. Variation in nectar volume and sugar concentration of Allium ursinum L. ssp. ucrainicum in three habitats. The Scientific World Journal 2012: 1-7. https://doi.org/10.1100/2012/138579

Felton A., Lindbladh M., BRUnet J. \& Fritz Ö. 2010. Replacing coniferous monocultures with mixed-species production stands: An assessment of the potential benefits for forest biodiversity in northern Europe. Forest Ecology and Management 260: 939-947.

https://doi.org/10.1016/j.foreco.2010.06.011 
Galetto L. \& Bernardello G. 2004. Floral nectaries, nectar production dynamics and chemical composition in six Ipomoea species (Convolvulaceae) in relation to pollinators. Annals of Botany 94: 269-280. https://doi.org/10.1093/aob/mch137

Gilbert F., Haines N. \& DiCKSON K. 1991. Empty flowers. Functional Ecology 5: 29-39. https://doi.org/10.2307/2389553

GóR Á. 2017. Kis Apolló-lepkék (Parnassius mnemosyne) táplálkozási stratégiáinak vizsgálata egyedi nyomonkövetéssel. Szakdolgozat. Állatorvostudományi Egyetem. 40 pp.

GouLSON D. 1999. Foraging strategies of insects for gathering nectar and pollen, and implications for plant ecology and evolution. Perspectives in Plant Ecology, Evolution and Systematics 2: 185209. https://doi.org/10.1078/1433-8319-00070

Halmágyi L. \& KereszTesi B. 1991. Méhlegelő. 2. kiadás. Akadémiai Kiadó, Budapest. 309 pp.

HANTSON S. \& BAZ A. 2013. Seasonal change in nectar preference for a mediterranean butterfly community. Journal of the Lepidopterists' Society 67: 134-142. https://doi.org/10.18473/lepi.v67i2.a5

Hegland S. J, Nielsen A, LÁzAro A, BJerknes A.-L. \& Totland Ø. 2009. How does climate warming affect plant-pollinator interactions? Ecology Letter 12: 184-195. https://doi.org/10.1111/j.1461-0248.2008.01269.x

Hejcman M., Hejcmanová P., Pavlů V. \& Beneš J. 2013. Origin and history of grasslands in Central Europe - A review. Grass and Forage Science 68: 345-363. https://doi.org/10.1111/gfs.12066

Helsdingen P. J. J. van, Willemse L. \& Speight M. C. D. (ed.) 1996. Background information on invertebrates of the habitats directive and the Bern Convention: Crustacea, Coleoptera and Lepidoptera. Council of Europe Publishing, Strasbourg, 529 pp.

Hicks D. M., Ouvrard P., Baldock K. C. R., Baude M., Goddard M. A., Kunin W. E., Mitschunas N., Memmott J., Morse H., Nikolitsi M., Osgathorpe L. M., Potts S. G., RoBertson K. M., Scott A. V., Sinclair F., Westbury D. B. \& Stone G. N. 2016. Food for pollinators: Quantifying the nectar and pollen resources of urban flower meadows. PLoS ONE 11: 137. https://doi.org/10.1371/journal.pone.0158117

Hilgartner, R., Raoilison, M., Büttiker, W., Lees, D. C. \& Krenn, H. W. 2007. Malagasy birds as hosts for eye-frequenting moths. Biology Letters 3: 117-120. https://doi.org/10.1098/rsbl.2006.0581

HiLl C. J. 1989. The effect of adult diet on the biology of butterflies - 2. The common crow butterfly, Euploea core corinna. Oecologia 81: 258-266. https://doi.org/10.1007/BF00379812

Hothorn T., HoRNiK K. \& ZeILEIS A. 2006. Unbiased recursive partitioning: A conditional inference framework. Journal of Computational and Graphical Statistics 15: 651-674. https://doi.org/10.1198/106186006X133933

JENNERSTEN O. 1984. Flower visitation and pollination efficiency of some North European butterflies. Oecologia 63: 80-89. https://doi.org/10.1007/BF00379789

JenNERSten O. 1988. Pollination in Dianthus deltoides (Caryophyllaceae): Effects of habitat fragmentation on visitation and seed set. Conservation Biology 2: 359-366. https://doi.org/10.1111/j.1523-1739.1988.tb00200.x

JOHNSON S. D. \& BOND W. J. 1994. Red flowers and butterfly pollination in the fynbos of South Africa. In: Arianoutsou-Faraggitaki, M. \& Groves, R. H. (ed.): Plant-animal interactions in Mediterranean-type ecosystems. Tasks for vegetation science. Springer, Dordrecht, pp. 137-148. https://doi.org/10.1007/978-94-011-0908-6_13 
KANDORi I. \& OHSAKi N. 1996. The learning abilities of the white cabbage butterfly, Pieris rapae, foraging for flowers. Researches on Population Ecology 38: 111-117. https://doi.org/10.1007/BF02514977

KeARns C. A. \& InOUYe D. W. 1993. Techniques for pollination biologists. University Press of Colorado, Niwot. 582 pp.

Kim W., Gilet T. \& Bush J. W. M. 2011. Optimal concentrations in nectar feeding. Proceedings of the National Academy of Sciences 108: 16618-16621.https://doi.org/10.1073/pnas.1108642108

Kitahara M., Yumoto M. \& Kobayashi T. 2008. Relationship of butterfly diversity with nectar plant species richness in and around the Aokigahara primary woodland of Mount Fuji, central Japan. Biodiversity and Conservation 17: 2713-2734. https://doi.org/10.1007/s10531-007-9265-4

Klotz S., KÜHN I., DuRkA W. \& Briemle G. 2002. BIOLFLOR: Eine Datenbank mit biologischökologischen Merkmalen zur Flora von Deutschland (Vol. 38). Bundesamt für Naturschutz, Bonn. http://www.ufz.de/biolflor/

Knopp M. C. N. \& KrenN H. W. 2003. Efficiency of fruit juice feeding in Morpho peleides (Nymphalidae, Lepidoptera). Journal of Insect Behavior 16(1): 67-77. https://doi.org/10.1023/A:1022849312195

KonvičKa M., Duchoslav M., Haraštová M., Beneš J., Foldynová S., Jirko̊ M. \& Kuras T. 2001. Habitat utilization and behaviour of adult Parnassius mnemosyne (Lepidoptera: Papilionidae) in the Litovelské Pomoraví, Czech Republic. Nota Lepidopterologica 24(4): 39-51.

KonviČKA M. \& KURAS T. 1999. Population structure, behaviour and selection of oviposition sites of an endangered butterfly, Parnassius mnemosyne, in Litovelské Pomoraví, Czech Republic. Journal of Insect Conservation 3: 211-223. https://doi.org/10.1023/A:1009641618795

KonviČKa M., VlasaneK P. \& HaUck D. 2006. Absence of forest mantles creates ecological traps for Parnassius mnemosyne (Papilionidae). Nota Lepidopterologica 29(1/2): 145-152.

KRENN H. W. 2001. Proboscis musculature in the butterfly Vanessa cardui (Nymphalidae, Lepidoptera): settling the proboscis recoiling controversy. Acta Zoologica 81: 259-266. https://doi.org/10.1046/j.1463-6395.2000.00055.x

KRENN H. W. 2010. Feeding mechanisms of adult Lepidoptera: structure, function, and evolution of the mouthparts. Annual Review of Entomology 55: 307-327. https://doi.org/10.1146/annurev-ento112408-085338

Kubo M., Kobayashi T., Kitahara M. \& Hayashi A. 2009. Seasonal fluctuations in butterflies and nectar resources in a semi-natural grassland near Mt. Fuji, central Japan. Biodiversity and Conservation 18: 229-246. https://doi.org/10.1007/s10531-008-9471-8

KudRnA O. \& SEUfERT W. 1991. Ökologie und Schutz von Parnassius mnemosyne in der Rhön Oedippus 2: 1-44. https://doi.org/10.1007/s10531-008-9471-8

Kugler H. 1970. Blütenökologie. Gustav Fischer, Stuttgart, 345 pp.

KUnIN W. E. 1997. Population size and density effects in pollination: Pollinator foraging and plant reproductive success in experimental arrays of Brassica kaber. The Journal of Ecology 85: 225. https://doi.org/10.2307/2960653

KuUsemets V., Meier K., Luig J. \& LiIVAmägi A. 2005. Habitat and landscape structure requirements of Clouded Apollo (Parnassius mnemosyne). In KüHN, E. (ed.): Studies on the Ecology and Conservation of Butterflies in Europe Pensoft, Sofia-Moscow, pp. 18-21.

KuUsSaAri M., Heliölä J., Pöyry J. \& SAarinen K. 2007. Contrasting trends of butterfly species preferring semi-natural grasslands, field margins and forest edges in northern Europe. Journal of Insect Conservation 1: 351-366. https://doi.org/10.1007/s10841-006-9052-7 
KuUsSaAri M., Rytteri S., HeikKinen R. K., Heliölä J. \& BAgh P. vOn 2016. Weather explains high annual variation in butterfly dispersal. Proceedings of the Royal Society B: Biological Sciences 283: 20160413. https://doi.org/10.1098/rspb.2016.0413

LARA RUIZ J. 2011. Fuentes nectaríferas de los Papilionidae ibéricos (Lepidoptera). Boletin de la SAE 18: $68-87$.

LEBEAU J., WeSSELINGH R. A. \& VAN DyCK H. 2016. Floral resource limitation severely reduces butterfly survival, condition and flight activity in simplified agricultural landscapes. Oecologia 180: 421-427. https://doi.org/10.1007/s00442-015-3492-2

LEwIS A. C. 1989. Flower visit consistency in Pieris rapae, the cabbage butterfly. The Journal of Animal Ecology 58: 1. https://doi.org/10.2307/4982

LiIVAmäGi A., KuUSEmets V., LuIg J. \& KASK K. 2013. Changes in the distribution of Clouded Apollo Parnassius mnemosyne (Lepidoptera: Papilionidae) in Estonia. Entomologica Fennica 24: 186-192. https://doi.org/10.33338/ef.8985

Luoto M., KuUssaAri M., Rita H., SALminen J. \& BonsdorfF T. von 2008. Determinants of distribution and abundance in the Clouded Apollo butterfly: A landscape ecological approach. Ecography 24: 601-617. https://doi.org/10.1111/j.1600-0587.2001.tb00494.x

MAHORO S. 2002. Individual flowering schedule, fruit set, and flower and seed predation in Vaccinium hirtum Thunb. (Ericaceae). Canadian Journal of Botany 80: 82-92. https://doi.org/10.1139/b01-136

Matter S.F., Ezzeddine M., Duermit E., Mashburn J., Hamilton R., Lucas T. \& Roland J., 2009. Interactions between habitat quality and connectivity affect immigration but not abundance or population growth of the butterfly, Parnassius smintheus. Oikos 118: 1461-1470. https://doi.org/10.1111/j.1600-0706.2009.17438.x

MAY P. G. 1992. Flower selection and the dynamics of lipid reserve in two nectarivorous butterflies. Ecology 73: 2181-2191. https://doi.org/10.2307/1941466

Meglécz E., Pecsenye K., Peregovits L. \& Varga Z. 1997. Allozyme variation in Parnassius mnemosyne (L.) (Lepidoptera) populations in North-East Hungary: Variation within a subspecies group. Genetica 101: 59-66. https://doi.org/10.1023/A:1018368622549

MeVI-SchÜtZ J. \& ERHARDT A. 2005. Amino acids in nectar enhance butterfly fecundity: A longawaited link. The American Naturalist 165: 411-419. DOI: https://doi.org/10.1086/429150

Michel F., Rebourg C., Cosson E. \& Descimon H. 2008. Molecular phylogeny of Parnassiinae butterflies (Lepidoptera: Papilionidae) based on the sequences of four mitochondrial DNA segments. Annales de la Société entomologique de France 44: 1-36. https://doi.org/10.1080/00379271.2008.10697541

NeUmAYeR J. \& SpAethe J. 2007. Flower color, nectar standing crop, and flower visitation of butterflies in an alpine habitat in Central Europe. Entomologia Generalis 29: 269-284. https://doi.org/10.1127/entom.gen/29/2007/269

NEW T. R. (ed.) 2012. Insect conservation: past, present and prospects. Springer Netherlands, Dordrecht. 436 pp. https://doi.org/10.1007/978-94-007-2963-6

New T. R., Pyle R. M., Thomas I. A., Thomas C. D. \& Hammond P. C. 1995. Butterfly conservation management. Annual Review of Entomology 40: 57-83. https://doi.org/10.1146/annurev.en.40.010195.000421

Nicolson S. W., Nepi M. \& PACini E. (ed.) 2007. Nectaries and Nectar. Springer. 408 pp. https://doi.org/10.1007/978-1-4020-5937-7 
Nilsson S. G., Franzén M. \& Pettersson L. 2013. Land-use changes, farm management and the decline of butterflies associated with semi-natural grasslands in southern Sweden. Nature Conservation 6: 31-48. https://doi.org/10.3897/natureconservation.6.5205

O’Brien D. M., Boggs C. L. \& Fogel M. L. 2003. Pollen feeding in the butterfly Heliconius charitonia: isotopic evidence for essential amino acid transfer from pollen to eggs. Proceedings of the Royal Society of London. Series B: Biological Sciences 270: 2631-2636. https://doi.org/10.1098/rspb.2003.2552

Омото K., Yonezawa T. \& Shinkawa T. 2009. Molecular systematics and evolution of the recently discovered "Parnassian" butterfly (Parnassius davydovi CHURKIN, 2006) and its allied species (Lepidoptera, Papilionidae). Gene 441(1-2): 80-88. https://doi.org/10.1016/j.gene.2008.10.030

OMURA H., Honda K., AsAOKA K. \& InOUe T. A. 2008. Tolerance to fermentation products in sugar reception: gustatory adaptation of adult butterfly proboscis for feeding on rotting foods. Journal of Comparative Physiology A 194(6): 545-555. https://doi.org/10.1007/s00359-008-0330-6

Parmesan C., Ryrholm N., Stefanescu C., Hill J. K., Thomas C. D., Descimon H., Kaila L., Kullberg J., Tammaru T., Tennent W. J., Thomas J. A. \& Warren M. 1999. Poleward shifts in geographical ranges of butterfly species associated with regional warming. Nature 399: 579-583. https://doi.org/10.1038/21181

PECSENYE K. 2017. Védett lepkék populációinak genetikai diverzitása. MTA doktori értekezés. Debreceni Egyetem. 160 pp.

Peitsch D., Fietz A., Hertel H., De Souza J., Ventura D. F. \& Menzel R. 1992. The spectral input systems of hymenopteran insects and their receptor-based colour vision. Journal of Comparative Physiology A 170(1): 23-40. https://doi.org/10.1007/BF00190398

Plotkin D. \& GodDard J. 2013. Blood, sweat, and tears: A review of the hematophagous, sudophagous, and lachryphagous Lepidoptera. Journal of Vector Ecology 38(2): 289-294. https://doi.org/10.1111/j.1948-7134.2013.12042.x

Potts S. G., Biesmeijer J. C., Kremen C., Neumann P., Schweiger O. \& Kunin W. E. 2010. Global pollinator declines: trends, impacts and drivers. Trends in Ecology \& Evolution 25: 345-353. https://doi.org/10.1016/j.tree.2010.01.007

Pratt G. F. \& WiesenborN W. D. 2009. Macneill's Sootywing (Hesperopsis gracielae) (Lepidoptera: Hesperiidae) behaviors observed along transects. Proceedings of the Entomological Society of Washington 111: 698-707. https://doi.org/10.4289/0013-8797-111.3.698

Pyke G. H., Pulliam H. R. \& Charnov E. L. 1977. Optimal foraging: A selective review of theory and tests. The Quarterly Review of Biology 52: 137-154. https://doi.org/10.1086/409852

R CORE TEAM 2018. R: A language and environment for statistical computing.

RIJN P. C. J. VAN \& WÄCKERS F. L. 2016. Nectar accessibility determines fitness, flower choice and abundance of hoverflies that provide natural pest control. Journal of Applied Ecology 53: 925933. https://doi.org/10.1111/1365-2664.12605

RODRÍGUEZ-GIRONÉS M. A. \& SANTAMARÍA L. 2004. Why are so many bird flowers red? PLoS Biology 2: e350. https://doi.org/10.1371/journal.pbio.0020350

RONKAY L. 1997. Nemzeti biodiverzitás monitorozó rendszer VII. Lepkék. Magyar Természettudományi Múzeum, Budapest. 70 pp.

Schoonhoven L. M., Loon J. J. A. van \& Marcel D. (ed.) 2005. Insect-plant biology. 2nd edition Oxford University Press, Wallingford. $440 \mathrm{pp}$.

Schweiger O., Heikkinen R. K., Harpke A., Hickler T., Klotz S., Kudrna O., KÜhn I., PÖyry J. \& SETTELE J. 2012. Increasing range mismatching of interacting species under global change is re- 
lated to their ecological characteristics. Global Ecology and Biogeography 21: 88-99. https://doi.org/10.1111/j.1466-8238.2010.00607.x

Settele J., Kudrna O., Harpke A., Kühn I., SwaAy C. van, Verovnik R., Warren M., Wiemers M., Hanspach J., Hickler T., Kühn E., Halder I. van, Verling K., Vliegenthart A., WyNhOFF I. \& SCHWEIGER O. 2008. Climatic risk atlas of European butterflies. BioRisk. SofiaMoscow. 711 pp. https://doi.org/10.3897/biorisk.1

SimBERLOFF D. 1998. Flagships, umbrellas, and keystones: Is single-species management passé in the landscape era? Biological Conservation 83: 247-257. https://doi.org/10.1016/S00063207(97)00081-5

Stang M., Klinkhamer P. G. L., Waser N. M., Stang I. \& Meijden,E. Van Der 2009. Size-specific interaction patterns and size matching in a plant-pollinator interaction web. Annals of Botany 103: 1459-1469. https://doi.org/10.1093/aob/mcp027

StefanesCu C. 1997. Migration patterns and feeding resources of the Painted Lady butterfly, Cynthia cardui (L.) (Lepidoptera, Nymphalidae) in the northeast of the Iberian peninsula. Miscel-lània Zoologica 20: 31-48.

SteFFAN-DEWENTER I. \& TSCHARNTKE T. 1999. Effects of habitat isolation on pollinator communities and seed set. Oecologia 121: 432-440. https://doi.org/10.1007/s004420050949

Stephens D. W., Brown J. S. \& Ydenberg R. C. (ed.) 2007. Foraging: behavior and ecology. The University of Chicago Press, Chicago. $626 \mathrm{pp}$.

Strobl C., BoulesteiX A.-L., Zeileis A. \& Hothorn T. 2007. Bias in random forest variable importance measures: Illustrations, sources and a solution. BMC Bioinformatics 8: 1-21. https://doi.org/10.1186/1471-2105-8-25

Sutherland R.J. (ed.) 2000. The conservation handbook: research, management and policy. The Energy Journal. Wiley. 296 pp. https://doi.org/10.1002/9780470999356

Swaay C. Van, Cuttelod A., Collins S., Maes D., Munguira M. L., Šašić M., Settele J., Verovnik R., Verstrael T., WARren M., WiEMERs M. \& Wynhof I. 2010. European red list of butterflies. Publications Office of the European Union, Luxembourg, 47 pp.

SzigeTI V. 2018. Nektárnövény kinálat és használat kis Apolló-lepkéknél (Parnassius mnemosyne). Doktori disszertáció. Állatorvostudományi Egyetem. 157 pp.

Szigeti V., Harnos A., Körösi Á., Bella M. \& Kis J. 2015. Kis Apolló-lepkék (Parnassius mnemosyne) élőhelyhasználata nektárforrásuk és lárvális tápnövényük függvényében. Természetvédelmi Közlemények 21: 1-10.

SZIGETI V., KÖRÖSI Á., HARNOS A. \& KIS J. 2018. Temporal changes in floral resource availability and flower visitation in a butterfly. Arthropod-Plant Interactions 12: 177-189. https://doi.org/10.1007/s11829-017-9585-6

SzIGETI V., KÖRÖSI Á., HARnos A., NAGY J. \& KIS J. 2016. Comparing two methods for estimating floral resource availability for insect pollinators in semi-natural habitats. Annales de la Société entomologique de France 52: 289-299. https://doi.org/10.1080/00379271.2016.1261003

Thomas R. C. \& Schultz C. B. 2016. Resource selection in an endangered butterfly: Females select native nectar species. The Journal of Wildlife Management 80: 171-180. https://doi.org/10.1002/jwmg.987

Tudor O., Dennis R. L. H., Greatorex-Davies J. N. \& Sparks T. 2004. Flower preferences of woodland butterflies in the UK: nectaring specialists are species of conservation concern. Biological Conservation 119: 397-403. https://doi.org/10.1016/j.biocon.2004.01.002 
VAlimaki P. \& ItAmies J. 2005. Effects of canopy coverage on the immature stages of the Clouded Apollo butterfly with observations on larval behaviour. Entomologica Fennica 16: 117-123. https://doi.org/10.33338/ef.84244

VARGa Z. 2006. KvVM Természetvédelmi Hivatal Fajmegörzési Tervek - Díszes tarkalepke. Környezetvédelmi és Vízügyi Minisztérium, Természetvédelmi Hivatal, Budapest. 21 pp.

Vojnits A. M. \& Ács E. 2000. Biology and behaviour of a Hungarian population of Parnassius mnemosyne (LinNAEUS, 1758). Oedippus 17: 1-24.

Wallisdevries M., SwaAy C. Van \& Plate C. 2012. Changes in nectar supply: A possible cause of widespread butterfly decline. Current Zoology 58: 384-391. https://doi.org/10.1093/czoolo/58.3.384

WARDHAUGH C. W. 2015. How many species of arthropods visit flowers? Arthropod-Plant Interactions 9: 547-565. https://doi.org/10.1007/s11829-015-9398-4

WeISS J.-C. 1999. The Parnassiinae of the world 3. Hardwickii-, Orleans-, Ariadne-, Eversmanni-, Mnemosyne Groups. Sciences Nat. Canterbury. 18 pp.

Willmer P. 2011. Pollination and Floral Ecology. Princeton University Press. Princeton, 792 pp. https://doi.org/10.23943/princeton/9780691128610.001.0001

WiLSON D. S. 1998. Adaptive individual differences within single populations. Philosophical Transactions of the Royal Society of London. Series B: Biological Sciences 353: 199-205. https://doi.org/10.1098/rstb.1998.0202

WiLson R. J. \& MACLEAN I. M. D. 2011. Recent evidence for the climate change threat to Lepidoptera and other insects. Journal of Insect Conservation 15: 259-268. https://doi.org/10.1007/s10841-010-9342-y

Witt T., JÜrgens A., GeYer R. \& GotTSBERger G. 1999. Nectar dynamics and sugar composition in flowers of Silene and Saponaria species (Caryophyllaceae). Plant Biology 1: 334-345. https://doi.org/10.1111/j.1438-8677.1999.tb00261.x 
Flower choice in Clouded Apollo butterflies

(Parnassius mnemosyne (LINNAEUS, 1758))

\title{
FLÓRA VAJNA*¹, VIKTOR SZIGETI ${ }^{2}$, ANDREA HARNOS ${ }^{3}$ and JÁNOS KIS ${ }^{1}$
}

\author{
${ }^{1}$ University of Veterinary Medicine, Budapest, Department of Ecology, 1077, Budapest, Rottenbiller utca 50. \\ ${ }^{2}$ Centre for Ecological Research, Lendület Ecosystem Services Research Group, 2163 Vácrátót, Alkotmány út \\ ${ }^{2.3}$ University of Veterinary Medicine, Budapest, Department of Biomathematics and Informatics, 1078, Budapest, \\ István utca 2.*E-mail: vajnaflora@yahoo.com
}

\section{ÁLLATTANI KÖZLEMÉNYEK (2021) 106(1-2): 11-37.}

\begin{abstract}
Animals choose among food resources according to their nutritional needs and opportunities. Butterflies are ideal model organisms to study resource use, since adults select among food resources, and are capable to adapt to dynamically changing supplies, although they usually feed regularly on the same plant species sequentially. Our aim was to study which plant species are visited by Clouded Apollo butterflies (Parnassius mnemosyne (LINNAEUS, 1758)) from all the available insectpollinated plants, and to understand which floral traits determine their choice. We monitored the butterflies by mark-resight for $5+2$ years in two closely-situated meadows. We estimated flower abundance by scanning. Floral traits were collected from the Biolflor database. Annual visit ratios changed significantly among plant species. We found great variability in the traits of available flowers and in flower availability between the investigated meadows. Choice was influenced by flower abundance, colour and structure, and the importance of insect pollination in one meadow, and only by abundance and colour in the other. Floral traits influencing choice may be related to each other. Flower visit patterns imply strong selectivity, and the differences between meadows suggest environmental impact. Clouded Apollos probably visit the most beneficial nectar-sources the most often. The presence of larval host-plants is essential for a butterfly to occupy a habitat. We believe that the presence of nectar plants is also a must, at least for some butterfly species.
\end{abstract}

Keywords: food availability, foraging, nectar source, plant-pollinator interactions, resource use 
1. táblázat (Melléklet): Kis apollólepke viráglátogatási arányok megoszlása (\%) különbözö években a Leány-kúti réten és a Hegyesden. Az NA (nincs adat) értékek azt mutatják, hogy az adott évben nem figyeltük meg a növényfajt a réten.

Table 1 (Appendix): Annual Clouded Apollo flower visit ratios (\%) at Leány-kúti rét and Hegyesd. NA-s denote plant species not observed (not available) in specific years.

látogatási arány (\%)

\begin{tabular}{|c|c|c|c|c|c|c|c|}
\hline \multirow{3}{*}{ növényfaj } & \multirow{2}{*}{\multicolumn{5}{|c|}{ Leány-kúti rét }} & \multirow{2}{*}{\multicolumn{2}{|c|}{ Hegyesd }} \\
\hline & & & & & & & \\
\hline & 2009 & 2010 & 2011 & 2012 & 2013 & 2014 & 2015 \\
\hline $\begin{array}{l}\text { Aegonychon purpurea- } \\
\text { coeruleum }\end{array}$ & 20,8 & 0,3 & 1,1 & 0,0 & 8,2 & 4,8 & 8,9 \\
\hline Ajuga genevensis & 1,1 & 2,0 & 1,4 & 0,4 & 3,8 & 3,4 & 1,7 \\
\hline Ajuga reptans & NA & NA & NA & NA & NA & 0,3 & 0,0 \\
\hline Anacamptis morio & 0,2 & 0,5 & 0,0 & 0,0 & 0,0 & 0,1 & 0,0 \\
\hline Anthyllis vulneraria & 0,0 & 0,0 & 0,0 & 0,0 & 0,0 & NA & NA \\
\hline Arabis sp. & 0,0 & 0,0 & 0,0 & 0,0 & 0,0 & 0,1 & 0,0 \\
\hline Berberis vulgaris & 0,0 & 0,0 & 0,0 & 0,0 & 0,0 & NA & NA \\
\hline Campanula persicifolia & NA & NA & NA & NA & NA & 0,0 & 0,0 \\
\hline Campanula rapunculus & 0,0 & 0,0 & 0,1 & 0,0 & 0,0 & 0,0 & 0,0 \\
\hline Capsella bursa-pastoris & NA & NA & NA & NA & NA & 0,0 & 0,0 \\
\hline Cerastium sp. & NA & NA & NA & NA & NA & 0,0 & 0,0 \\
\hline Clematis integrifolia & 0,0 & 0,0 & 0,0 & 0,0 & 0,0 & NA & NA \\
\hline Colutea arborescens & NA & NA & NA & NA & NA & 0,0 & 0,0 \\
\hline Cornus mas & NA & NA & NA & NA & NA & 0,0 & 0,0 \\
\hline Cornus sanguinea & NA & NA & NA & NA & NA & 0,1 & 0,0 \\
\hline Cota tinctoria & 0,0 & 0,0 & 0,0 & 0,0 & 0,0 & 0,0 & 0,0 \\
\hline Crataegus monogyna & 0,0 & 0,0 & 0,0 & 0,4 & 0,0 & 0,0 & 0,0 \\
\hline Cydonia oblonga & NA & NA & NA & NA & NA & 0,0 & 0,0 \\
\hline Cynoglossum officinale & NA & NA & NA & NA & NA & 0,0 & 0,0 \\
\hline Dianthus collinus & 0,0 & 0,0 & 0,0 & 0,0 & 0,0 & NA & NA \\
\hline $\begin{array}{l}\text { Dianthus giganteiformis } \\
\text { subsp. pontederae }\end{array}$ & 21,3 & 48,3 & 15,2 & 60,4 & 42,8 & 73,6 & 70,3 \\
\hline Dictamnus albus & 0,0 & 0,0 & 0,0 & 0,0 & 0,0 & NA & NA \\
\hline Digitalis grandiflora & NA & NA & NA & NA & NA & 0,0 & 0,0 \\
\hline Eremogone procera & 0,0 & 0,2 & 0,6 & 0,4 & 0,6 & NA & NA \\
\hline Euonymus verrucosus & 0,0 & 0,0 & 0,0 & 0,0 & 0,0 & NA & NA \\
\hline Euphorbia cyparissias & 0,2 & 0,2 & 0,2 & 0,0 & 0,0 & 0,2 & 0,0 \\
\hline Euphorbia epithymoides & NA & NA & NA & NA & NA & 0,0 & 0,0 \\
\hline Ficaria verna & 0,0 & 0,0 & 0,0 & 0,0 & 0,0 & NA & NA \\
\hline Filipendula vulgaris & 0,0 & 0,2 & 0,3 & 0,7 & 0,0 & NA & NA \\
\hline Fragaria viridis & 6,2 & 9,2 & 16,2 & 15,9 & 1,3 & 0,5 & 0,3 \\
\hline Fraxinus ornus & 0,0 & 0,0 & 0,0 & 0,0 & 0,0 & 0,0 & 0,0 \\
\hline
\end{tabular}


1. táblázat (Melléklet) (Folytatás)

Table 1 (Appendix) (Continued)

látogatási arány (\%)

\begin{tabular}{|c|c|c|c|c|c|c|c|}
\hline \multirow[b]{3}{*}{ növényfaj } & \\
\hline & \multicolumn{5}{|c|}{ Leány-kúti rét } & \multicolumn{2}{|c|}{ Hegyesd } \\
\hline & 2009 & 2010 & 2011 & 2012 & 2013 & 2014 & 2015 \\
\hline Galium glaucum & NA & NA & NA & NA & NA & 0,1 & 0,0 \\
\hline Galium sp. & 0,0 & 0,0 & 0,0 & 0,0 & 0,0 & NA & NA \\
\hline Genista tinctoria & 0,0 & 0,0 & 0,0 & 0,0 & 0,0 & 0,0 & 0,0 \\
\hline Geranium robertianum & 0,0 & 0,0 & 0,0 & 0,0 & 0,0 & NA & NA \\
\hline Geranium sanguineum & NA & NA & NA & NA & NA & 2,6 & 3,3 \\
\hline Geum urbanum & 0,0 & 0,0 & 0,0 & 0,0 & 0,0 & 0,0 & 0,0 \\
\hline Helianthemum ovatum & 0,0 & 0,0 & 0,0 & 0,0 & 0,0 & NA & NA \\
\hline Helianthemum sp. & NA & NA & NA & NA & NA & 0,0 & 0,0 \\
\hline Hieracium bauhini & 0,0 & 0,0 & 0,0 & 0,0 & 0,0 & 0,3 & 0,0 \\
\hline Hypochaeris oligocephala & NA & NA & NA & NA & NA & 0,0 & 0,0 \\
\hline Inula hirta & 0,0 & 0,2 & 0,5 & 0,0 & 1,3 & 0,2 & 0,2 \\
\hline Iris graminea & NA & NA & NA & NA & NA & 0,0 & 0,0 \\
\hline Iris variegata & NA & NA & NA & NA & NA & 0,0 & 0,0 \\
\hline Lamium purpureum & 0,0 & 0,6 & 0,0 & 0,0 & 0,0 & 0,1 & 0,0 \\
\hline Lathyrus latifolius & 0,0 & 0,0 & 0,0 & 0,0 & 0,0 & NA & NA \\
\hline Lathyrus nissolia & 0,0 & 0,0 & 0,0 & 0,0 & 0,0 & 0,0 & 0,0 \\
\hline Lathyrus tuberosus & NA & NA & NA & NA & NA & 0,0 & 0,0 \\
\hline Leopoldia comosa & NA & NA & NA & NA & NA & 0,0 & 0,0 \\
\hline Lepidium campestre & 0,0 & 0,0 & 0,0 & 2,2 & 2,5 & 0,0 & 0,0 \\
\hline Leucanthemum vulgare & 0,0 & 0,0 & 0,1 & 0,0 & 0,0 & 0,1 & 0,1 \\
\hline Ligustrum vulgare & 0,0 & 0,0 & 0,0 & 0,0 & 0,0 & NA & NA \\
\hline Lithospermum arvense & NA & NA & NA & NA & NA & 0,0 & 0,0 \\
\hline Lotus corniculatus & 0,0 & 0,0 & 0,1 & 0,0 & 0,0 & NA & NA \\
\hline Melampyrum cristatum & 0,0 & 0,0 & 0,0 & 0,0 & 0,0 & NA & NA \\
\hline Myosotis stricta & 0,0 & 0,3 & 0,1 & 0,0 & 0,0 & 0,1 & 0,0 \\
\hline Orchis mascula & NA & NA & NA & NA & NA & 0,0 & 0,0 \\
\hline $\begin{array}{l}\text { Ornithogalum orthophyllum } \\
\text { subsp. kochii }\end{array}$ & 0,0 & 0,0 & 0,0 & 0,0 & 0,0 & NA & NA \\
\hline Orobanche sp. & NA & NA & NA & NA & NA & 0,0 & 0,0 \\
\hline Plantago $s p$ & 0,0 & 0,0 & 0,0 & 0,0 & 0,0 & NA & NA \\
\hline Polygala comosa & 4,4 & 9,1 & 3,9 & 0,4 & 2,5 & 0,0 & 0,0 \\
\hline Polygonatum odoratum & NA & NA & NA & NA & NA & 0,0 & 0,0 \\
\hline Potentilla sp. & 0,0 & 0,0 & 0,4 & 0,0 & 0,0 & 0,1 & 0,0 \\
\hline Primula veris & NA & NA & NA & NA & NA & 0,0 & 0,0 \\
\hline Prunus spinosa & NA & NA & NA & NA & NA & 0,0 & 0,0 \\
\hline
\end{tabular}


1. táblázat (Melléklet) (Folytatás)

Table 1 (Appendix) (Continued)

látogatási arány (\%)

\begin{tabular}{|c|c|c|c|c|c|c|c|}
\hline \multirow[b]{3}{*}{ növényfaj } & \\
\hline & \multicolumn{5}{|c|}{ Leány-kúti rét } & \multicolumn{2}{|c|}{ Hegyesd } \\
\hline & 2009 & 2010 & 2011 & 2012 & 2013 & 2014 & 2015 \\
\hline Pseudolysimachion spicatum & 0,0 & 0,0 & 0,0 & 0,0 & 0,0 & 0,1 & 0,0 \\
\hline Ranunculus acris & NA & NA & NA & NA & NA & 0,3 & 0,0 \\
\hline Ranunculus illyricus & 0,0 & 0,0 & 0,0 & 0,0 & 0,6 & NA & NA \\
\hline Ranunculus polyanthemos & 0,5 & 4,4 & 3,2 & 1,9 & 1,3 & NA & NA \\
\hline Rhinanthus minor & 0,0 & 0,0 & 0,0 & 0,0 & 1,3 & NA & NA \\
\hline Robinia pseudoacacia & NA & NA & NA & NA & NA & 0,0 & 0,0 \\
\hline Rosa canina & 0,0 & 0,0 & 0,0 & 0,0 & 0,0 & 0,1 & 0,0 \\
\hline Rosa gallica & 0,0 & 0,0 & 0,0 & 0,0 & 0,0 & 0,0 & 0,0 \\
\hline Salvia nemorosa & 0,0 & 0,0 & 0,4 & 3,7 & 0,0 & NA & NA \\
\hline Salvia pratensis & NA & NA & NA & NA & NA & 0,1 & 0,0 \\
\hline Sambucus nigra & 0,0 & 0,0 & 0,0 & 0,0 & 0,0 & NA & NA \\
\hline Sanguisorba minor & 0,0 & 0,0 & 0,0 & 0,0 & 0,0 & NA & NA \\
\hline Saxifraga bulbifera & 0,2 & 0,2 & 1,0 & 0,0 & 0,0 & 0,1 & 0,0 \\
\hline Scorzonera laciniata & 0,0 & 0,0 & 0,1 & 0,0 & 0,0 & NA & NA \\
\hline Silene nutans & 0,0 & 0,0 & 0,0 & 0,0 & 0,0 & 0,0 & 0,0 \\
\hline Silene viscaria & 36,5 & 9,8 & 44,5 & 8,9 & 18,2 & 7,4 & 8,0 \\
\hline Silene vulgaris & NA & NA & NA & NA & NA & 0,0 & 0,0 \\
\hline Stachys recta & NA & NA & NA & NA & NA & 0,0 & 0,0 \\
\hline Stellaria graminea & 0,0 & 0,0 & 0,0 & 0,0 & 0,0 & NA & NA \\
\hline Stellaria holostea & 0,0 & 0,2 & 0,0 & 0,0 & 0,0 & 0,0 & 0,0 \\
\hline Symphytum tuberosum & NA & NA & NA & NA & NA & 0,0 & 0,0 \\
\hline Syringa vulgaris & NA & NA & NA & NA & NA & 0,2 & 0,1 \\
\hline Tanacetum corymbosum & 0,0 & 0,0 & 0,0 & 0,0 & 0,0 & NA & NA \\
\hline Taraxacum officinale & 0,0 & 0,0 & 0,0 & 0,0 & 0,0 & NA & NA \\
\hline Thymus odoratissimus & 0,2 & 3,3 & 1,0 & 0,0 & 10,7 & 0,7 & 0,3 \\
\hline Tragopogon orientalis & NA & NA & NA & NA & NA & 0,0 & 0,0 \\
\hline Trifolium alpestre & 0,0 & 0,2 & 1,0 & 0,0 & 0,0 & 2,1 & 0,2 \\
\hline Trifolium campestre & 0,0 & 0,0 & 0,0 & 0,0 & 0,0 & 0,0 & 0,0 \\
\hline Trifolium montanum & 1,3 & 4,2 & 3,2 & 4,1 & 5,0 & 0,5 & 0,0 \\
\hline Trifolium pratense & 4,5 & 3,1 & 2,5 & 0,0 & 0,0 & NA & NA \\
\hline Trifolium repens & 0,0 & 0,0 & 0,3 & 0,0 & 0,0 & NA & NA \\
\hline Valerianella locusta & NA & NA & NA & NA & NA & 0,0 & 0,0 \\
\hline Verbascum phoeniceum & 0,0 & 0,2 & 0,0 & 0,0 & 0,0 & 0,1 & 0,0 \\
\hline Veronica austriaca & 0,0 & 0,0 & 0,0 & 0,0 & 0,0 & NA & NA \\
\hline Veronica chamaedrys & 0,3 & 0,3 & 0,7 & 0,0 & 0,0 & 0,0 & 0,0 \\
\hline
\end{tabular}


1. táblázat (Melléklet) (Folytatás)

Table 1 (Appendix) (Continued)

látogatási arány $(\%)$

\begin{tabular}{lrrrrr|rr} 
& \multicolumn{9}{c|}{ Leány-kúti rét } & \multicolumn{2}{c}{ Hegyesd } \\
\cline { 2 - 8 } \multicolumn{1}{c}{ növényfaj } & $\mathbf{2 0 0 9}$ & $\mathbf{2 0 1 0}$ & $\mathbf{2 0 1 1}$ & $\mathbf{2 0 1 2}$ & $\mathbf{2 0 1 3}$ & $\mathbf{2 0 1 4}$ & $\mathbf{2 0 1 5}$ \\
\cline { 2 - 8 } & 0,0 & 0,0 & 0,0 & 0,0 & 0,0 & 0,0 & 0,0 \\
Veronica teucrium & 0,0 & 0,0 & 0,0 & 0,0 & 0,0 & 0,4 & 0,3 \\
Vicia angustifolia & 2,4 & 3,3 & 1,9 & 0,0 & 0,0 & 1,9 & 5,6 \\
Vicia cracca & $\mathrm{NA}$ & $\mathrm{NA}$ & $\mathrm{NA}$ & $\mathrm{NA}$ & $\mathrm{NA}$ & 0,0 & 0,0 \\
Vicia sp. & 0,0 & 0,0 & 0,0 & 0,7 & 0,0 & 0,0 & 0,0 \\
Vincetoxicum hirundinaria & 0,0 & 0,0 & 0,0 & 0,0 & 0,0 & 0,3 & 0,0 \\
Viola arvensis & \multicolumn{7}{c}{0,0} \\
\hline
\end{tabular}

2. táblázat (Melléklet): A növényfajok számának megoszlása a kis apollólepke látogatottság függvényében különböző években a Leány-kúti réten és a Hegyesden.

Table 2 (Appendix): Distribution of the number of plant species according to Clouded Apollo visit ratios (categorised) in the studied years at Leány-kúti rét and Hegyesd. Column sub-headers show visit categories (from left to right; non-visited, visited $<1 \%,>1 \%$ except the 4 most visited, the 4 most visited species in a specific year, and in grey: all visited species and all insect-pollinated species.

\begin{tabular}{|c|c|c|c|c|c|c|c|c|}
\hline & & & \multicolumn{6}{|c|}{ megfigyelt látogatottság } \\
\hline & & & $\begin{array}{l}\text { nem lá- } \\
\text { togatott }\end{array}$ & $<1 \%$ & $\begin{array}{c}1 \%<\text { (kivéve } \\
\text { évi } 4 \text { leg- } \\
\text { gyakrabban } \\
\text { látogatott) }\end{array}$ & $\begin{array}{l}\text { évi } 4 \text { leg- } \\
\text { gyakrabban } \\
\text { látogatott }\end{array}$ & $\begin{array}{l}\text { össze- } \\
\text { sen lá- } \\
\text { togatott }\end{array}$ & $\begin{array}{c}\text { összes } \\
\text { rovar- } \\
\text { porozta }\end{array}$ \\
\hline \multirow{9}{*}{ 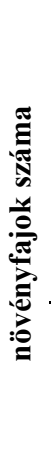 } & \multirow{6}{*}{$\begin{array}{l}\text { Leány-kúti } \\
\text { rét }\end{array}$} & 2009 & 56 & 6 & 5 & 4 & 15 & 71 \\
\hline & & 2010 & 48 & 13 & 6 & 4 & 23 & 71 \\
\hline & & 2011 & 45 & 16 & 6 & 4 & 26 & 71 \\
\hline & & 2012 & 58 & 6 & 3 & 4 & 13 & 71 \\
\hline & & 2013 & 57 & 2 & 8 & 4 & 14 & 71 \\
\hline & & $\begin{array}{l}2009- \\
2013 \\
\end{array}$ & 36 & 18 & 10 & 7 & 35 & 71 \\
\hline & \multirow{3}{*}{ Hegyesd } & 2014 & 49 & 19 & 3 & 4 & 26 & 75 \\
\hline & & 2015 & 57 & 12 & 2 & 4 & 18 & 75 \\
\hline & & $\begin{array}{l}2014- \\
2015\end{array}$ & 44 & 24 & 2 & 5 & 31 & 75 \\
\hline
\end{tabular}

